\title{
Sixty years after 'The mastodonts of Brazil': The state of the art of South American proboscideans (Proboscidea, Gomphotheriidae)
}

\author{
Dimila Mothé ${ }^{\mathrm{a}, \mathrm{b},{ }^{*}, \text { Leonardo dos Santos Avilla }}{ }^{\mathrm{a}, \mathrm{c}}$, Lidiane Asevedo ${ }^{\mathrm{a}, \mathrm{d}}$, \\ Leon Borges-Silva a, Mariane Rosas ${ }^{e}$, Rafael Labarca-Encina ${ }^{\mathrm{f}}$, Ricardo Souberlich ${ }^{\mathrm{g}}$, \\ Esteban Soibelzon ${ }^{\text {h, i }}$, José Luis Roman-Carrion ${ }^{\mathrm{j}}$, Sergio D. Ríos ${ }^{\mathrm{k}}$, Ascanio D. Rincon ${ }^{\text {, }}$ \\ Gina Cardoso de Oliveira ${ }^{\mathrm{b}}$, Renato Pereira Lopes ${ }^{\mathrm{m}}$
}

\footnotetext{
a Laboratório de Mastozoologia, Departamento de Zoologia, Instituto de Biociencias, Universidade Federal do Estado do Rio de Janeiro, Av. Pasteur, 458, 501, Urca, CEP 22290-240, Rio de Janeiro, Brazil

b Programa de Pós-graduação em Geociências, Centro de Tecnologia e Geociências, Universidade Federal de Pernambuco, Rua Acadêmico Hélio Ramos, s/n, Cidade Universitária,

CEP 50740-467, Recife, Brazil

c Programa de Pós-graduação em Biodiversidade Neotropical, Instituto de Biociências, Universidade Federal do Estado do Rio de Janeiro, Av. Pasteur, 458, 501, Urca, CEP 22290-240, Rio de Janeiro, Brazil

d Faculdade de Geociências (Fageo), Campus Cuiabá, Universidade Federal de Mato Grosso, Av. Fernando Correa da Costa, 2367, Jardim Petrópolis, CEP 78070-000, Cuiabá, Mato Grosso, Brazil

e Laboratório de Paleontologia, Centro de Ciências Agrárias, Ambientais e Biológicas, Universidade Federal do Recôncavo da Bahia, Cruz das Almas, Bahia, Brazil

${ }^{\mathrm{f}}$ Laboratorio de Paleoecología, Instituto de Ciencias Ambientales y Evolutivas, Universidad Austral de Chile, Casilla 567, Valdivia, Chile

${ }^{\mathrm{g}}$ Laboratorio de Paleontología, Departamento de Geología, Facultad de Ciencias Exactas y Naturales, Acceso Av. Mcal. Lopez, Universidad Nacional de

Asunción, Paraguay

h Division Paleontología Vertebrados, Museo de La Plata, Facultad de Ciencias Naturales y Museo, Universidad Nacional de La Plata, Paseo del Bosque s/n, 1900, La Plata, Argentina

${ }^{\mathrm{i}}$ CONICET, Argentina

${ }^{j}$ Museo de Historia Natural "Gustavo Orcés V.", Instituto de Ciências Biológicas, Escuela Politécnica Nacional, Ladrón de Guevara E11-253, Casilla Postal 17-01-2759, Quito, Ecuador

${ }^{\mathrm{k}}$ Departamento de Arqueología y Paleontología Secretaria Nacional de Cultura, Paraguay

${ }^{1}$ Instituto Venezolano de Investigaciones Científicas, Laboratorio de Paleontologia, Centro de Ecología, Km 11 de la Carretera Panamericana, Apartado Postal 20632, Caracas 1020A, Venezuela

m Programa de Pós-Graduação em Geociências, UFRGS, Av. Bento Gonçalves, 9500, CEP 91540-000, Porto Alegre, Rio Grande do Sul, Brazil
}

\section{A R T I C L E I N F O}

\section{Article history:}

Available online 30 September 2016

\section{Keywords:}

Notiomastodon

Cuvieronius

Proboscidea

Extinction

Paleoecology

Taxonomy

\begin{abstract}
A B S T R A C T
Studies on South American Gomphotheriidae started around 210 years ago and, 150 years later, the classic study "The mastodonts of Brazil" by Simpson and Paula Couto (1957) attempted to clarify the complex issues related to our understanding of these proboscideans. Here, we update state of knowledge regarding proboscideans in South America subsequent to the publication of Simpson and Paula Couto (1957). The taxonomy of South American proboscideans is now stable and two species are recognized, Notiomastodon platensis and Cuvieronius hyodon. The former had a wide distribution in South America (from lowlands to highlands and from east to west coasts), while the latter was restricted to Ecuador, Peru and Bolivia. Although records of Notiomastodon are abundant and occur in almost overlapping geographic distribution with Cuvieronius, they have never been recorded in the same locality. Here, we evaluated over 500 South American localities with proboscidean remains, although only cranial and dental specimens show recognizable diagnostic features. As both proboscideans in South America had a generalist-opportunist alimentary strategy, a competitive exclusion probably precluded their sympatry. Their origin is most probably related to independent migrations from Central America during the Great
\end{abstract}

\footnotetext{
* Corresponding author. Laboratório de Mastozoologia, Departamento de Zoologia, Instituto de Biociências, Universidade Federal do Estado do Rio de Janeiro, Av. Pasteur 458, sala 501, Urca, CEP 22290-240, Rio de Janeiro, Brazil.

E-mail addresses: dimothe@hotmail.com (D. Mothé), leonardo.avilla@gmail.com (L. dos Santos Avilla), lidi.asevedo@gmail.com (L. Asevedo), leonbsilva@hotmail.com

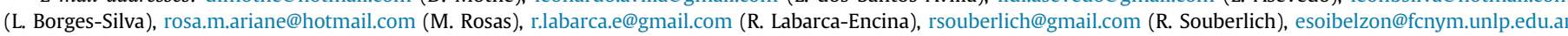

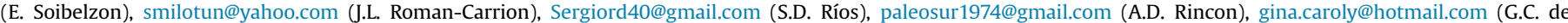
Oliveira), paleonto_furg@yahoo.com.br (R.P. Lopes).
} 
American Biotic Interchange. They are not sister-taxa - Cuvieronius hyodon is sister-taxon of Rhynchotherium, and this clade is closer to Notiomastodon platensis than to the other proboscideans, supporting the hypothesis of independent origins. Notiomastodon platensis has a continuous record from the Early Pleistocene to Early Holocene, when it became extinct, probably due to synergy of human impact and climatic changes during the Pleistocene/Holocene transition. In contrast, extinction of Cuvieronius hyodon happened much earlier, and it was not related to the terminal Pleistocene event that lead the extinction of selected megafauna in South America, including Notiomastodon.

(c) 2016 Elsevier Ltd and INQUA. All rights reserved.

\section{Introduction}

After the publication of the first record of a South American proboscidean 210 years ago (Cuvier, 1806), the taxonomic history of this group had several chapters, and most researchers consider the revision of Simpson and Paula Couto (1957) a watershed (Prado et al., 2005; Shoshani and Tassy, 2005; Ferretti, 2010). Why is this classic paper so important? It comprises the first effort in 150 years to review the taxonomy and to congregate information on proboscideans from many localities in South America; a contrast to previous traditional taxonomical studies that frequently proposed new names. The only exception is Cabrera (1929), a paper that was most certainly the basis of the study by Simpson and Paula Couto (1957). In the following six decades, due to more critical studies, the taxonomy of South American proboscideans further stabilized (Mothé et al., 2012; Mothé and Avilla, 2015). Inspired by Simpson and Paula Couto (1957), here we gathered a group of South American researchers to present the current state of the knowledge on taxonomy, phylogeny, geographic distribution, chronology and the feeding paleoecology of South American proboscideans.

\section{Materials and methods}

The information presented here includes a detailed survey of the literature of the last 210 years, since the first record of Proboscidea in South America (Cuvier, 1806). We also comment and make new inferences on taxonomy, geographic distribution, systematics and paleoecology based on more recently collected data. The specimens of proboscideans from all over South America were, for the first time, catalogued in a single database (Supplementary Materials Table 1), reviewed and classified according to the current proposed taxonomic classification (Mothé and Avilla, 2015). Each South American locality with a record of Proboscidea was georeferenced with the help of the software Google Earth Pro ${ }^{\mathrm{TM}}$. The localities were plotted according to their geographic description in the literature or, when the coordinates were absent from the original publication, we estimated the most suitable geographic position according with Google Earth Pro ${ }^{\mathrm{TM}}$. The localities with diagnostic remains of Cuvieronius hyodon and Notiomastodon platensis were used to construct an updated distribution map of these proboscideans in South America (Supplementary Materials Interactive Google Earth Map). Non-diagnostic specimens were also plotted in order to consolidate knowledge of geographic occurrences of South American proboscideans.

\section{Results and discussion}

\subsection{The timeline of 210 years of taxonomic issues}

The complex taxonomic history of South American proboscideans began more than two centuries ago with only two intermediate molars collected by Humboldt (Fig. 1), one found near the volcano Imbabura, Quito, Ecuador, and the other probably from
Concepción, Chile (Cuvier, 1806). Both specimens were described and figured by Cuvier (1806), who failed to assign generic or specific names (binomial system of Linnaeus) in their descriptions and referred to them using the informal terms "mastodonte des cordillères" and "mastodonte humboldien”, respectively (Fig. 2).

Fischer (1814) proposed the first valid specific name, Mastotherium hyodon, for the specimen from Ecuador ("mastodonte des cordillères"), and Cuvier (1824) later formally named these materials as Mastodon andium (specimen from Ecuador) and Mastodon humboldtii (specimen from Chile). However, the name Mastotherium hyodon had priority over the name $M$. andium proposed by Cuvier (1824). Nevertheless, the isolated teeth described by Cuvier $(1806,1824)$ and Fischer (1814) are not diagnostic to any bunodont proboscidean at the specific level, based on recent diagnoses, and they could represent either of the South American taxa, including the same taxon (Mastotherium hyodon and/or Mastodon humboldtii; Ficcarelli et al., 1995; Ferretti, 2008; Lucas, 2008).

Lund (1839) mentioned some proboscidean remains from Lagoa Santa, Minas Gerais State in Brazil, but he gave no classification, description or illustration of the specimens (a nomen nudum), and Lesson (1842) listed only the name "Mastodon brasiliensis Lund". Almost seven decades later, when describing the specimens mentioned by Lund (1839), Winge (1906) referred to them as "Mastodon andium", although Mastotherium hyodon had priority over this name for almost a century (Fig. 2). Furthermore, Winge (1906) did not validate the name "Mastodon brasiliensis". Only in Hoffstetter (1952), when he properly published a systematic description of "Stegomastodon brasiliensis", was the name credited to Lund and became valid. However, it was antedated by several other names proposed before his study (see Cabrera, 1929; Simpson and Paula Couto, 1957; Ferretti, 2008; Lucas, 2008; and Fig. 2).

At the end of the 19th century and beginning of 20th century, Ameghino published several studies on South American proboscideans $(1888 ; 1889 ; 1891 ; 1902)$, especially on materials from Argentina. In these studies, he named several species of the genus Mastodon, including Mastodon bonaerensis, M. argentinus, M. platensis, $M$. superbus, M. maderianus, $M$. tarijensis and $M$. rectus. Those species were distinguished by size, upper tusks features and complexity of molar morphology, although Ameghino mentioned the occurrence of individual variation (Cabrera, 1929). Holland (1920) described the species Mastodon waringi based on several specimens from Pedra Vermelha, Bahia State in Brazil, collected by Gerald Waring in 1912 (housed at the Carnegie Museum of Natural History, CM:VP:11033 series), but did not figure the specimens. Simpson and Paula Couto (1957) indicated that the specimens described by Holland (1920) as M. waringi did not distinguish this species clearly from others related to the genus Mastodon and all remains from Brazil known at that time could probably be recognized as a single species.

Two years later, Proaño (1922) published the species name Masthodon chimborazi, preceded by some partial publications in 1894 and 1903 (Hoffstetter, 1952; Ficcarelli et al., 1995; Ferretti, 2010). This species was based on a proboscidean skeleton from 


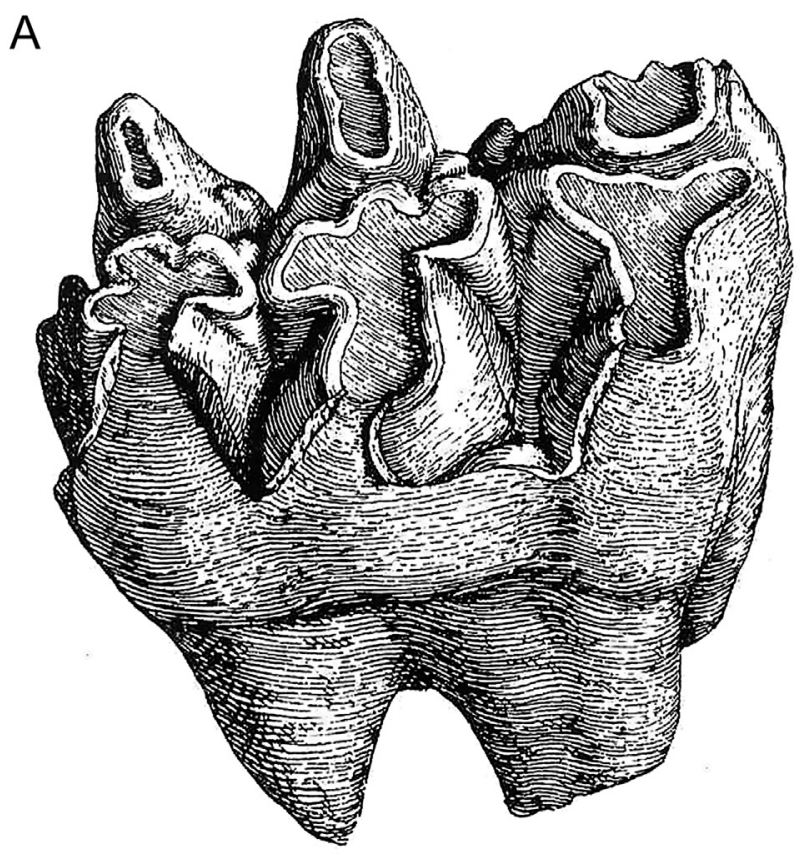

B

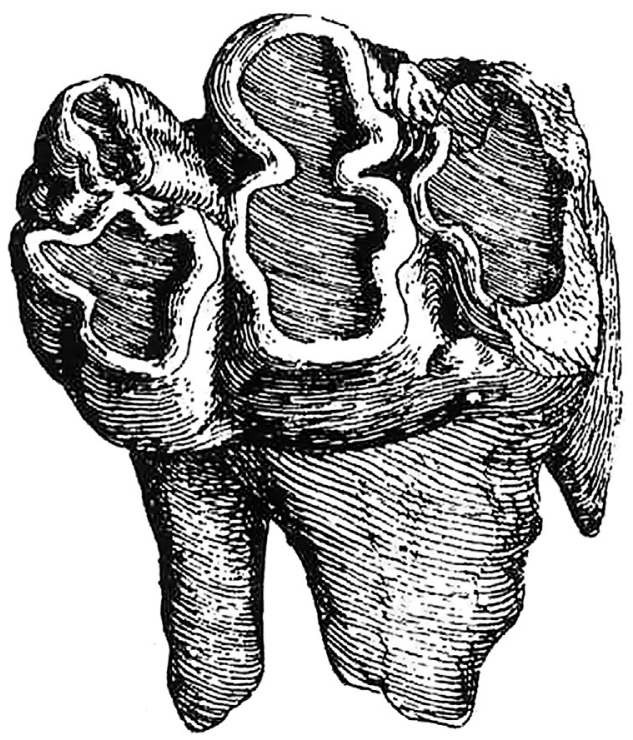

Fig. 1. The proboscidean molars collected by Humboldt and described by Cuvier (1806) from South America. A) The "mastodonte des cordillères"; B) The "mastodonte humboldien". Modified from Osborn (1936).

Quebrada de Chalán, near Punin, Chimborazo, Ecuador. Ferretti (2010) argued that although the species name Masthodon chimborazi appeared before 1922 in internal records, the study by Proaño meets all the criteria set by ICZN (1999) for the species name Masthodon chimborazi to be considered valid (Fig. 2).

Osborn (1923) described the genus Cuvieronius based on the specimens previously identified as Mastodon humboldtii from South American lowlands, and later (Osborn, 1926) described the genus Cordillerion based on the specimens from the Andes previously described as Mastodon andium (instead of Mastotherium hyodon, proposed by Fischer, 1814).

In his review of Argentinian proboscideans, Cabrera (1929) considered Cordillerion as a junior synonym of Cuvieronius and applied this name to the Andean proboscidean, using Mastotherium hyodon as its type species, a classification followed by subsequent authors (Hoffstetter, 1950, 1952; Simpson and Paula Couto, 1957;
Tobien, 1973; Shoshani and Tassy, 1996; Alberdi et al., 2002, 2004; Prado et al., 2002, 2003, 2005; Prado and Alberdi, 2008; Mothé and Avilla, 2015; Mothé et al., 2016). Lucas (2008) indicated that Cabrera (1929) probably wanted to use the oldest valid species name for what he recognized as a single South American species of Cuvieronius, even though $M$. humboldtii was the originally designated type species (a violation of the ICZN rules, Article 68.2 as currently articulated in ICZN, 1999). Cabrera (1929) also synonymyzed several species of the genus Mastodon described by Ameghino $(1888,1889 ; 1891 ; 1902)$ with the genus Stegomastodon. These included Stegomastodon platensis and Stegomastodon superbus, although Cabrera (1929) pointed out differences in the number of pairs of cusps in the molars of North American (Osborn, 1924) and South American species of Stegomastodon. Cabrera (1929) also described a new genus and species endemic to South America, Notiomastodon ornatus, based on specimens from Playa del Barco, Monte Hermoso, Buenos Aires, Argentina, characterized by lateral enamel band on upper tusks.

Osborn (1936) did not agree with the taxonomic proposal of Cabrera (1929) and considered only the genera Cuvieronius, Cordillerion and Notiomastodon as valid for South America (Fig. 2). Some subsequent authors agreed with the taxonomy of Osborn (Madden, 1984; Ficcarelli et al., 1995; Ferretti, 2008; Mothé et al., 2012, 2016; Lucas, 2013; Mothé and Avilla, 2015), although others did not follow the taxonomic hypothesis of Osborn (1936), accepting the presence of the genus Stegomastodon in South America (Hoffstetter, 1950, 1952; Simpson and Paula Couto, 1957; Alberdi and Prado, 1995; Shoshani and Tassy, 1996; Alberdi et al., 2002, 2004; Prado et al., 2003, 2005; Prado and Alberdi, 2008).

Hoffstetter (1950) reviewed proboscideans materials from Ecuador and coined the name Haplomastodon as a subgenus of Stegomastodon. Later, based on the presence/absence of transverse foramina on the atlas and axis, he designated a full generic separation of Haplomastodon from Stegomastodon (Hoffstetter, 1952), including the separation of the former into the subgenera Haplomastodon and Aleamastodon (Fig. 2). Thus, according to Hoffstetter, the valid proboscidean species from South America included Cuvieronius hyodon, Notiomastodon ornatus, Haplomastodon (Haplomastodon) chimborazi, Haplomastodon (Aleamastodon) guayasensis, Stegomastodon (Stegomastodon) platensis and Stegomastodon (Stegomastodon) superbus.

In the 1940's, several individuals representing a single population of proboscideans were discovered in association in the deposit of Águas de Araxá, Minas Gerais State in Brazil. They were described by Simpson and Paula Couto (1957) and recognized by these authors as Haplomastodon (following Hoffstetter's recognition of Haplomastodon as a valid genus distinct from Stegomastodon). Although Hoffstetter (1952) had designated Mastodon chimborazi as the type species of Haplomastodon, Simpson and Paula Couto (1957) considered Mastodon waringi as its type species and synonymized Haplomastodon chimborazi with Haplomastodon waringi (see Ferretti, 2010). Based on priority, Simpson and Paula Couto (1957) argued that since the volume in which Haplomastodon chimborazi appeared is dated 1922, and the diagnosis of Mastodon waringi was published in October, 1920, this species name would have priority over $H$. chimborazi. In addition, Simpson and Paula Couto (1957) also considered the Ecuadorian specimens of proboscideans studied by Hoffstetter as the same species as the Brazilian forms. Thus, Simpson and Paula Couto (1957) recognized four valid genera in South America: Stegomastodon, Haplomastodon, Notiomastodon and Cuvieronius (Fig. 2), and subsequent studies perpetuated their classification. In the 1980's, Madden (1984) suggested that South American species related to Stegomastodon actually could represent a distinct genus with respect to the North American 


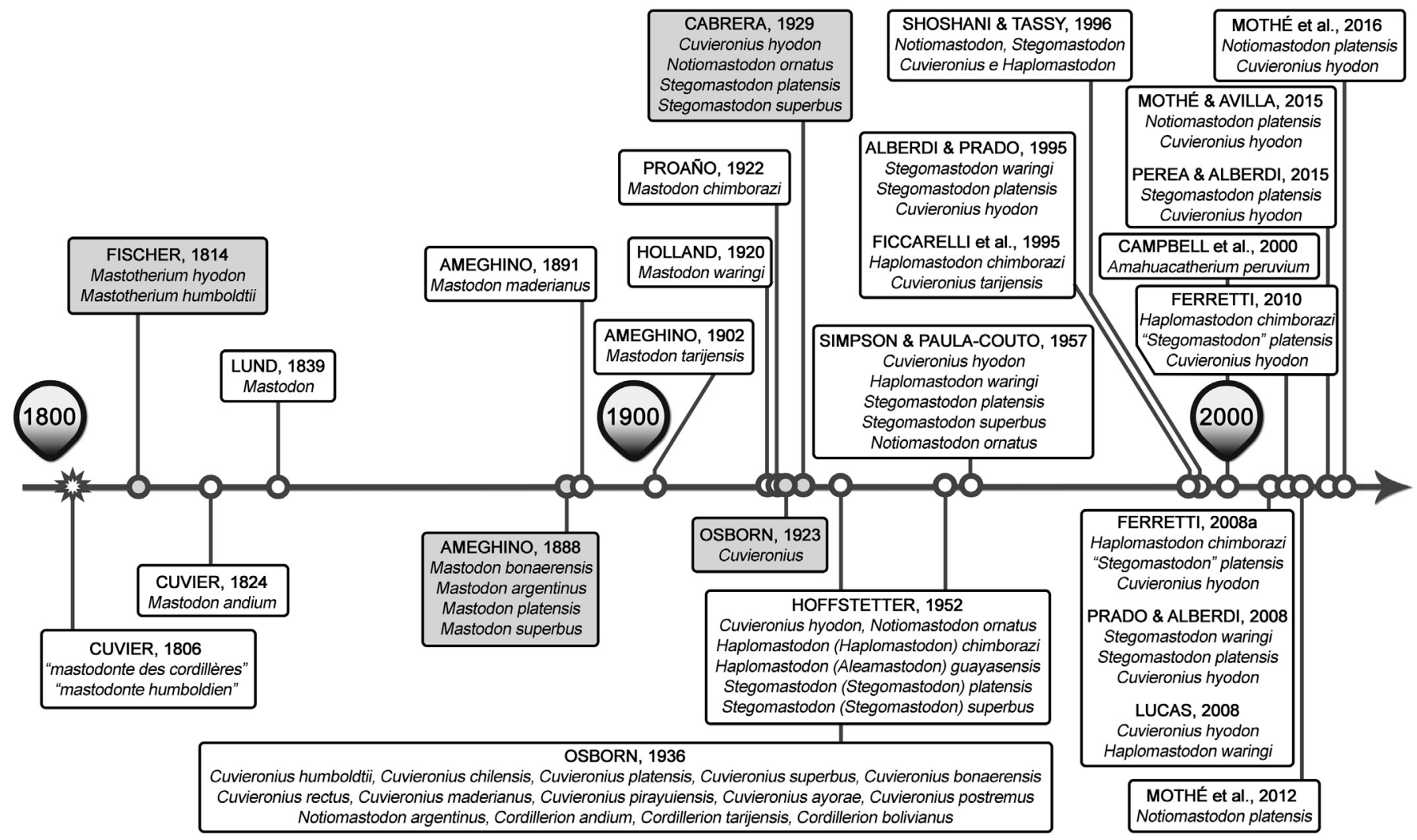

Fig. 2. Timeline of the taxonomic history of South American proboscideans from 1806 to 2016. The grey boxes represent the studies where current names first appeared.

form, and suggested the use of the name Notiomastodon for the South American species included in Stegomastodon.

Ficcarelli et al. (1995) recognized the problematic taxonomy of South American proboscidean specimens, proposing the use of the specific epithet "tarijensis", and designating a skull and mandible from Tarija (MNHN TAR 1270, described by Boule and Thevenin, 1920) as the type of Cuvieronius tarijensis. In addition, based on Haplomastodon described by Simpson and Paula Couto (1957) and Hoffstetter (1952), Ficcarelli et al. (1995) concluded that Haplomastodon was a valid genus, distinct from South American Stegomastodon. Since $M$. waringi was defined on fragmentary and nondiagnostic materials (CM:VP:11033 series) and it was not figured in its original description by Holland (1920), it should be considered as a nomen dubium (Ferretti, 2010). The holotype of Masthodon chimborazi was lost in a fire in 1929 (Ferretti, 2008) and Ficcarelli et al. (1995) proposed a neotype for this taxon: a skull, lower jaw and partial postcranial elements of a single individual from Quebrada Pistud, Bolivar, Ecuador (MECN 82, 83, 84 and 1330). Then, Ficcarelli et al. (1995) considered three proboscidean species valid for South America: Cuvieronius tarijensis, Haplomastodon chimborazi and Stegomastodon platensis.

In the same year, Alberdi and Prado (1995) pointed out that the morphological differences between species of Haplomastodon and Stegomastodon platensis were very superficial, and they considered Haplomastodon a junior synonym of Stegomastodon, in which they include both North and South American species. Thus, according to Alberdi and Prado (1995) the valid species of South American proboscideans were Cuvieronius hyodon, Stegomastodon platensis and Stegomastodon waringi (Fig. 2). Subsequent studies on South American proboscideans followed the taxonomic proposal of Alberdi and Prado (1995), perpetuating recognition of
Stegomastodon in South America and several taxonomic problems concerning the validity of the epithets "waringi" and "chimborazi" (Prado et al., 2001, 2002, 2003, 2005; Alberdi et al., 2002, 2004, 2007; Prado and Alberdi, 2008).

A year later, Shoshani and Tassy (1996) published the masterpiece study on proboscideans, and recognized the validity of four genera in South America: Cuvieronius, Stegomastodon, Notiomastodon and Haplomastodon. Further, complicating the debate on the diversity of South American proboscideans, Campbell et al. (2000) described a new genus of proboscidean from the Late Miocene of Peru: Amahuacatherium peruvium. This taxon was based on fragmentary specimens from the Contamana Group, including a fragmentary mandible with second and third molars. Amahuacatherium was diagnosed as having two pairs of tusks (upper and lower pairs), and brevirostrine mandible with molars with complex enamel pattern. The validity of this taxon is highly controversial (Campbell et al., 2009; Mothé et al., 2013) and several authors questioned its diagnostic features and controversial age (Alberdi et al., 2004; Shoshani and Tassy, 2005; Ferretti, 2008, 2010; Lucas, 2013; Mothé and Avilla, 2015).

In 2008, Ferretti published a synthesis of the taxonomic history of South American proboscideans, focusing on the classic studies of Cabrera (1929), Hoffstetter (1950, 1952), Simpson and Paula Couto (1957) and Prado et al. (2005), and argued that the taxonomy of South American taxa was deeply in need of a thorough revision. Ferretti (2008) presented new records of South American proboscideans that supported the recognition of Stegomastodon from the continent as Notiomastodon (as hypothesized by Madden, 1984), although this author retained use of "Stegomastodon" platensis in the article. Ferretti (2008) considered Cuvieronius hyodon and Haplomastodon waringi as 
valid taxa, and subsequently raised issue about use of the name H. chimborazi (Ferretti, 2010).

Lucas (2008; 2009a; 2009b) proposed some solutions for the taxonomic issues of South American proboscideans in order to preserve the stability and universality of the most popular and long used nomenclature (Simpson and Paula-Couto, 1957; Alberdi and Prado, 1995; Prado et al., 2003, 2005; Prado and Alberdi, 2008). He proposed to formally designate Mastodon waringi as the type species of Haplomastodon by designating it a diagnostic neotype (the specimen designated by Ficcarelli et al., 1995; as neotype of $H$. chimborazi; Lucas, 2009a); and to consider Mastotherium hyodon as the formally designated type species of Cuvieronius, with a diagnostic neotype (the skull and mandible specimens from Tarija, Bolivia, previously published by Boule and Thevenin, 1920; Lucas, 2009b).

In 2010, Ferretti published a revision of several Haplomastodon specimens from Bolivar, Ecuador, and considered this genus as monospecific ( $H$. chimborazi), rejecting Lucas' (2009a) proposal to designate a diagnostic neotype for Mastodon waringi, and considering Haplomastodon waringi an invalid taxon as it was based on undiagnosed material (Ferretti, 2010). Attempts to designate diagnostic neotypes for Haplomastodon species (Ficcarelli et al., 1995; Lucas, 2009a) were rejected by the ICZN (Opinion 2308) in 2012, and Haplomastodon is considered a nomen dubium (Lucas, 2013). Additional action by the ICZN (Opinion 2276) has stabilized the Cuvieronius name by establishing the diagnostic neotype for the type species, Cuvieronius hyodon, as suggested by Lucas (2009b).

Mothé et al. (2012) conducted a review of the South American proboscideans and compared a large sample identified in literature as "Stegomastodon" platensis, "S." waringi and Haplomastodon chimborazi, in which specimens from the continent were reviewed. The diagnostic characters proposed in literature for South American species of Stegomastodon and H. chimborazi were considered as morphological variations (when large samples are analysed). Thus, Mothé et al. (2012) concluded that there was no support for more than one species in South American lowlands, and the specimens represent a single species: Notiomastodon platensis. Several authors followed this taxonomic proposition, but others still consider Stegomastodon as present in South America (see Mothé and Avilla, 2015; for more detailed discussion).

In 2015, Mothé and Avilla published an additional review of South American proboscideans, considering the diversity of all taxa from the continent, and concluded that the South American fauna includes only two taxa: Cuvieronius hyodon and Notiomastodon platensis (Figs. 2 and 3). Diagnostic features of Amahuacatherium peruvium were considered to be invalid and within the morphological variability range expected for $N$. platensis (Mothé and Avilla, 2015), as argued previously (Alberdi et al., 2004; Ferretti, 2008; Lucas, 2013). South American remains previously associated to Stegomastodon were compared with North American specimens, and they preserve very different features of the molars, mandible and skull (Mothé and Avilla, 2015; Mothé et al., 2016) and some features in post-cranial elements (for further details see Lucas et al., 2011), corroborating a hypothesis that the genus Stegomastodon is absent from South America.

The hypothesis that only two proboscideans are recorded in South America is now a consensus (Mothé et al., 2012; Mothé and Avilla, 2015; Perea and Alberdi, 2015; Alberdi and Prado, 2016; Mothé et al., 2016), and the main discussion about South American proboscideans concerns the presence of Stegomastodon on the continent (Perea and Alberdi, 2015; Alberdi and Prado, 2016). Although the taxonomy of Cuvieronius hyodon seems to be well established, the taxonomy of the second South American species is still under debate. Several authors agree with the validity of $N$. platensis (see more details in Mothé and Avilla, 2015), but there remains an alternative interpretation, where Stegomastodon platensis is still recognized as valid and present in South America (Perea and Alberdi, 2015; Alberdi and Prado, 2016).

All phylogenetic analysis, which included North American species of Stegomastodon and the problematic South American proboscidean (Stegomastodon platensis, Haplomastodon chimborazi or Notiomastodon platensis), place those taxa in separate and distant lineages (see Ferretti, 2010; Mothé et al., 2016; Mothé unpublished data). Consequently, we reiterate here that no specimen with diagnostic features of Stegomastodon is recognized in South America, and the genus is restricted to North America. In addition, we consider S. platensis as a junior synonym of $N$. platensis and that only this proboscidean, together with Cuvieronius hyodon, are recorded in South America.

Notiomastodon platensis is characterized by a cranium with large forehead and relatively horizontally-oriented rostrum in lateral view (Fig. 3). The incisive fossa is slightly developed or vestigial and the alveoli of upper tusks are slightly diverging. The upper tusks are never twisted and exhibit great morphological variation in length, robustness and shape. Enamel may be present on the upper tusks and can be shaped as a single lateral band or covering the entire tusk in juvenile and some adult individuals. The upper tusks have a circular to oval cross section and the lower tusks are absent (Fig. 3A, $\mathrm{B})$. The mandible is brevirostrine and it has a rounded profile, with long ascending ramus, which is nearly perpendicular to the mandible body. The molariforms of intermediate dentition are trilophodont, while the last one is tetra-pentalophodont and usually composed by 35-82 main and accessory cusps, forming simple or double-trefoil wear patterns (for more details see Mothé et al., 2012; Mothé and Avilla, 2015).

In turn, Cuvieronius hyodon is diagnosed by a flattened cranium with large forehead and laterally enlarged parieto-occipital crest. The lateral borders of premaxillary bones are very divergent and the incisive fossa is deep (Fig. 3C). Upper tusks are usually straight/ slightly upturned, elongated and always twisted, and may vary from parallel to divergent, with a sub-circular cross section. In addition, a longitudinal enamel band is present, following the tusk torsion (Fig. 3C). The mandible is brevirostrine and has a rounded profile, with deflected symphysis and long ascending ramus, which is nearly perpendicular to the mandible body. The intermediate molariforms are trilophodont, and the last molariform is tetralophodont and formed by 33-60 main and accessory cusps. The molariforms of Cuvieronius wear in simple to clean double trefoil patterns (Mothé and Avilla, 2015). Several juvenile specimens of Cuvieronius were recognized as having alveoli for lower incisors on the anterior portion of mandibular symphysis (Fig. 3D and E) and two individuals were recorded as having the small pair of lower incisors preserved (Liendo-Lazarte, 1946; Ferretti, 2008; Mothé et al., 2016; and Fig. 3F). Thus, Cuvieronius was recently recognized as a tetrabelodont proboscidean for the first time in literature (Prado and Alberdi, 2008; Ferretti, 2010; Lucas and Alvarado, 2010; Mothé et al., 2013), although only the twisted upper pair of tusks is apparent in adult individuals.

\subsection{Geographic distribution}

Based on the accumulation of information on over 500 localities in South America with proboscidean records (Interactive Google Earth Map), we observed that the geographic distribution of Notiomastodon platensis and Cuvieronius hyodon included both highlands and lowlands in South America (Mothé and Avilla, 2015). Since the first descriptions of South American proboscideans, records of Cuvieronius hyodon were thought to be associated to the uplands (Andean Cordillera), while the records of the other ( $N$. 


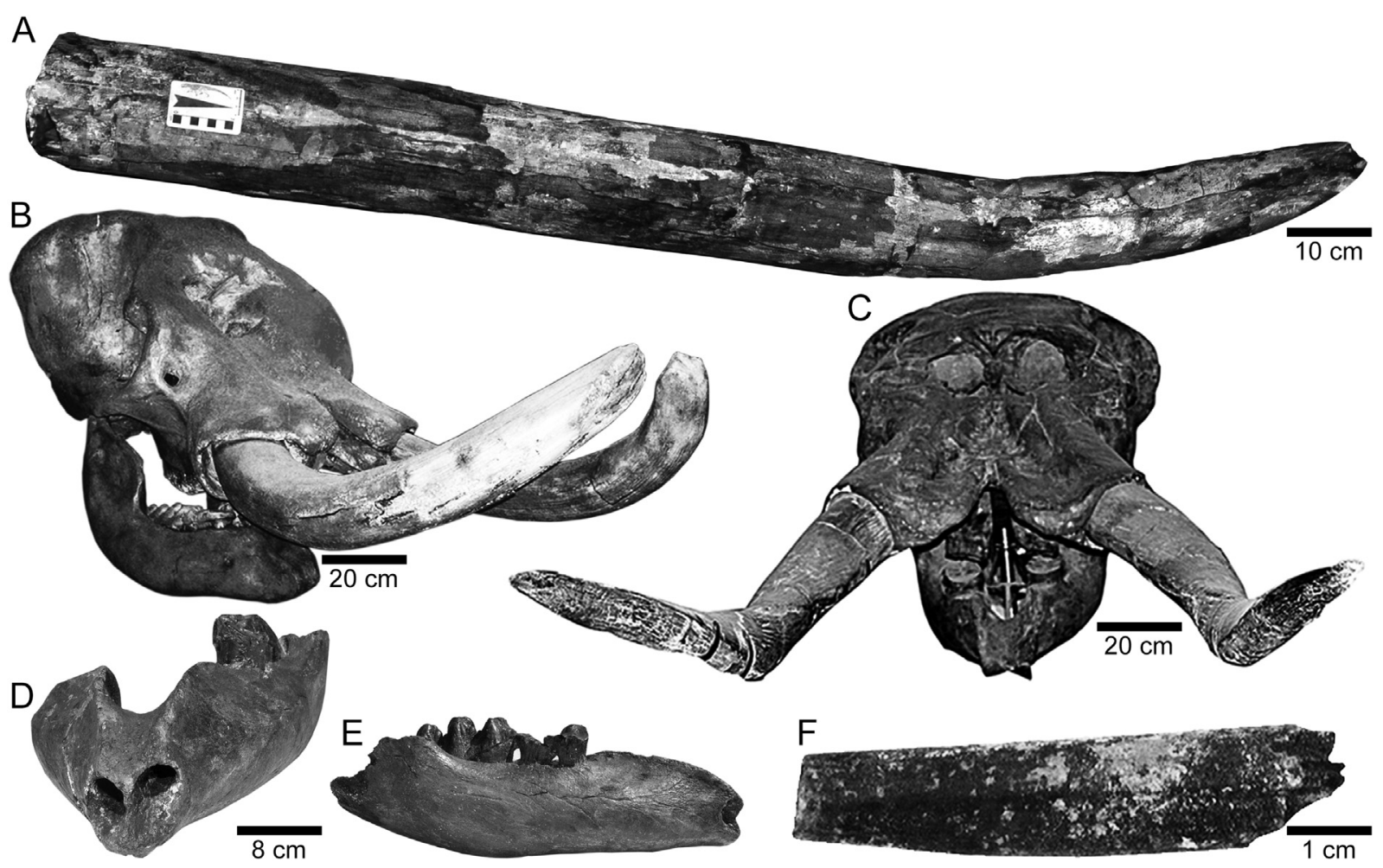

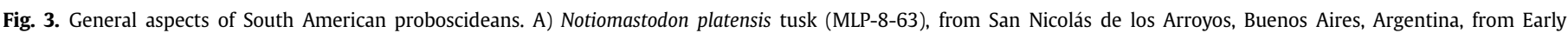

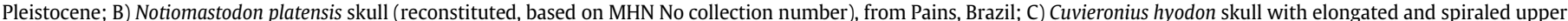

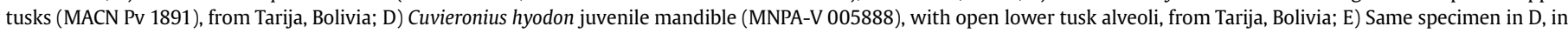
lateral view; E) Cuvieronius hyodon radical fragment of a right lower tusk (MNPA-V 005867) from Tarija, Bolivia.

platensis) were related to the lowlands (Cabrera, 1929; Osborn, 1936; Simpson and Paula Couto, 1957; Prado et al., 2005).

Mothé and Avilla (2015) argued that because of a proposed "two route dispersion" hypothesis (Alberdi and Prado, 1995; Prado et al., 2003), identifications of proboscideans in South America were frequently based on a circular argument: if the specimen was recorded on a lowland of south or east South America, it was recognized as Stegomastodon (=Notiomastodon platensis); but if it was from the Andes it was recognized as Cuvieronius hyodon. Thus, the taxonomy of South American proboscideans was based primarily on geographic distribution, and not on recognition of diagnostic morphological features. Therefore, following the morphological revisions of Mothé et al. (2012) and Mothé and Avilla (2015), the diagnostic specimens of South American proboscideans revealed a different geographical distribution pattern.

Notiomastodon platensis is widely recorded in nearly all countries of South America (except for Guyana, French Guiana and Suriname) from Andean localities in Colombia (Nemocon, Cundinamarca), Ecuador (Punin, Chimborazo) and Peru (Leclishpampa, Lima) to several lowland localities in Argentina, Chile, Brazil, Paraguay and Uruguay (Prado et al., 2003; Mothé et al., 2012; Mothé and Avilla, 2015) (Fig. 4). Cuvieronius hyodon is recognized only in Bolivia, Peru and Ecuador, also from lowlands to Andean localities (Fig. 4). In fact, South American localities of Cuvieronius hyodon are rare, although the materials from Tarija (Bolivia) are abundant (Boule and Thevenin, 1920; Mothé et al., 2016). The unique lowland record for Cuvieronius hyodon in South America is from La Huaca, Piura, northwestern Peru (see Interactive Google Earth Map). This record is a complete skull of an adult with fragmented upper tusks, material described previously by Alberdi et al. (2004) as Stegomastodon, and revised by Mothé and Avilla (2015). In North and Central America,
Cuvieronius hyodon also occurred from lowland to highlands localities, up to 3000 MASL (Arroyo-Cabrales et al., 2007; Lucas, 2008; Lucas and Alvarado, 2010). Mothé and Avilla (2015) argued that the discontinuous biogeographical distribution of Cuvieronius in northern South America may suggest that this taxon is absent from this area or, more likely, that diagnostic remains are or not yet recovered. The traditional idea of an exclusive "typical altitude" to identify South American proboscideans should no longer be used.

The generalist-opportunist diet strategy recognized by Asevedo et al. (2012) and Asevedo (2015) for N. platensis and C. hyodon could help to explain why both taxa occur in highlands and lowlands of Andean region. The vegetation belts of the Andes changed their altitudinal pattern in accordance with climatic fluctuations during the Pleistocene (e.g., Van der Hammen, 1974; Hooghiemstra and Ran, 1994, and others). During glacial periods, when humidity and temperature dropped, all vegetation belts lowered from their original altitudes, and likely allowed Cuvieronius hyodon to reach the lowland of La Huaca, in Peru (25 MASL). In contrast, during the interglacial periods, when humidity and temperature increased, all vegetation belts increased in altitude from their original heights, and both South American proboscideans reached high Andean altitudes, such as in Leclishpampa (Lima, Peru; 3892 MASL) for $N$. platensis and Ayusbamba (Cuzco, Peru; 3600 MASL) for C. hyodon.

Currently, there is not a locality where $N$. platensis and C. hyodon occur in sympatry (temporal and/or geographic), although both were recorded in close proximity in Ecuador and were present in Peru and Bolivia (see Fig. 4 and Interactive Google Earth Map). In addition, several localities in these countries have records of nondiagnostic materials, which could be Notiomastodon, Cuvieronius or even both taxa occurring possibly in sympatry. Colombia, has only diagnostic records of Notiomastodon, but the presence of $C$. hyodon 


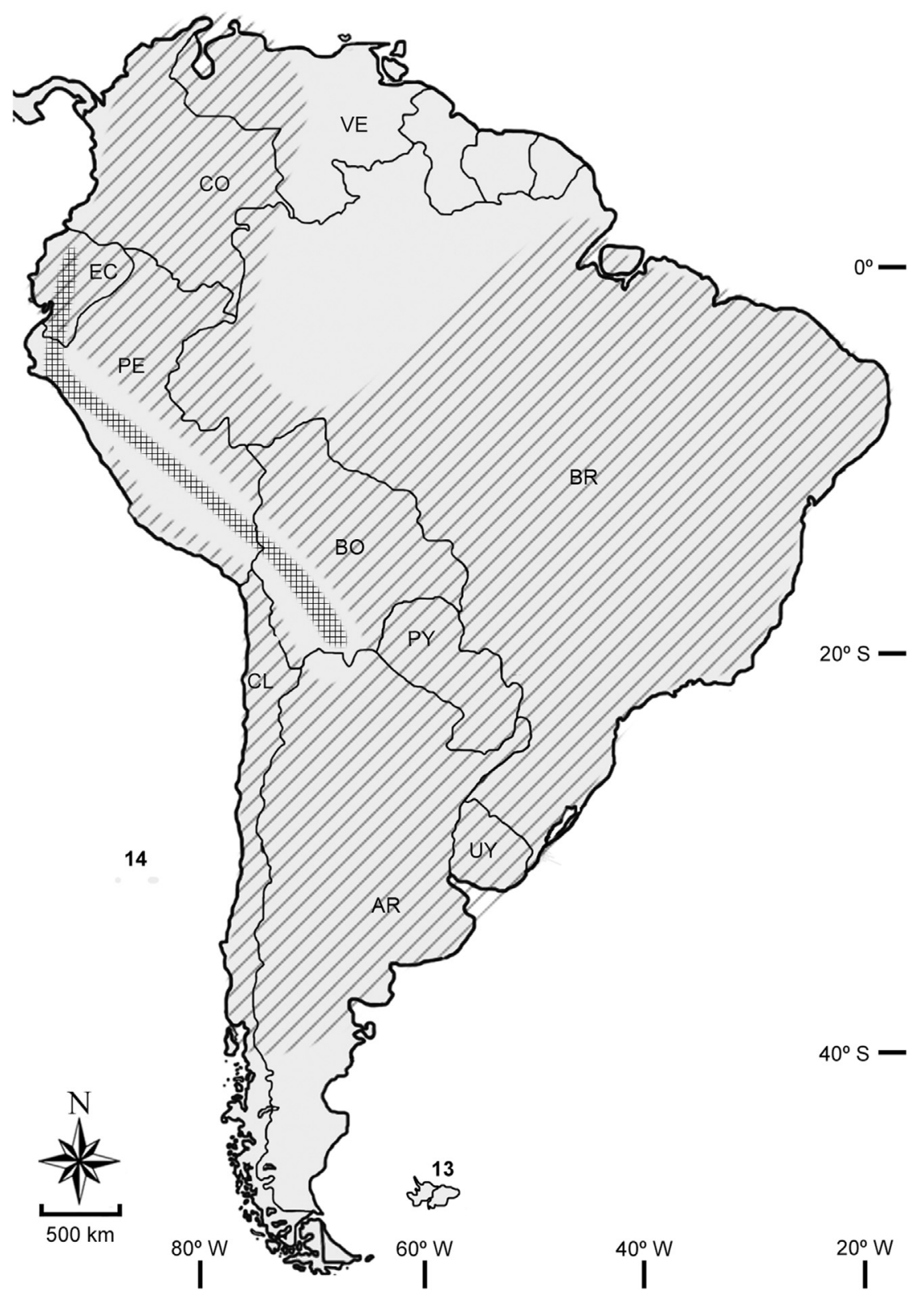

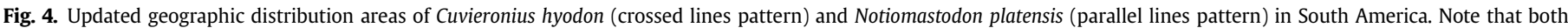
areas overlap only in Ecuador.

in Central America and other parts of South America, suggests that it should have occurred in this country. However, it is important to emphasize that although the remains of South American proboscideans are relatively abundant in comparison to other fossil groups from the Quaternary, most of the diagnostic characters of Notiomastodon and Cuvieronius are limited to cranial and dentition elements (Fig. 3). In this way, post-cranial elements and fragmented and/or isolated specimens are not diagnosable to generic level. There is an urgent need to identify diagnostic features in postcranial and/or isolated elements of Notiomastodon and Cuvieronius, in order to increase the accuracy of the records, geographic distribution and phylogenetic relationship of these proboscideans.

\subsection{Phylogenetic relationships of South American proboscideans}

Phylogenetic studies including South American proboscideans began in the 1980s (Tassy, 1985, 1996; Shoshani, 1996; Shoshani and Tassy, 2005; Prado and Alberdi, 2008; Ferretti, 2010; Cozzuol et al., 2012; Mothé et al., 2013, 2016). However, phylogenetic analysis of Gomphotheriidae is extremely fluid because of the complex and problematic taxonomy of this group (Ficcarelli et al., 1995; Ferretti, 2008; Mothé et al., 2012; Lucas, 2013; Mothé and Avilla, 2015). Usually, diagnostic features of gomphotheres are restricted to the skull, mandible and dentition, and cladistic studies rarely consider large samples, individual variation and polymorphisms (Shoshani and Tassy, 1996; Prado and Alberdi, 2008; Ferretti, 2010; Cozzuol et al., 2012; Mothé et al., 2012, 2016).

One phylogenetic hypothesis for Gomphotheriidae (Shoshani, 1996) recovered a clade including Eubelodon, Rhynchotherium, Sinomastodon, Notiomastodon, Haplomastodon, Stegomastodon and Cuvieronius. However, the clade was poorly supported only by an ambiguous synapomorphy (the absence of permanent premolars), the diagnostic features of the taxa were problematic and missing data was frequent. Prado and Alberdi (2008) published a 
phylogenetic hypothesis of trilophodont gomphotheres, with emphasis on the South American species. These authors found Sinomastodon as the sister group of a clade formed by Cuvieronius hyodon, Stegomastodon platensis and Stegomastodon waringi ( $N$. platensis in Mothé et al., 2012). However, some problems with this phylogenetic hypothesis include poor taxon sampling, exclusion of North American species of Stegomastodon (i.e., this genus was represented only by the controversial South American species), inadequate choice of outgroup, use of outdated software and methodology, and several misconceptions in coding of characters (see Cozzuol et al., 2012). Those issues raise concerns about the phylogenetic hypothesis itself as well as the biogeographic analysis of Alberdi et al. (2007) based on it. Cozzuol et al. (2012) reviewed the original character matrix of Prado and Alberdi (2008), but considered polymorphism for South American taxa in the analysis. The resulting consensus tree had a poor resolved topology, with Rhynchotherium, Sinomastodon, Gnathabelodon, Eubelodon and a clade of the South American taxa included in a polytomy, and the polytomy was situated as the sister-group of Gomphotherium (Cozzuol et al., 2012).

Ferretti (2010) was the first to recover a monophyletic clade including the genera Sinomastodon, Stegomastodon (represented by North American species), Cuvieronius, Rhynchotherium and Notiomastodon (="Stegomastodon" platensis and Haplomastodon chimborazi). However, the phylogenetic relationship between Notiomastodon platensis and Cuvieronius hyodon were not well resolved in his hypothesis, since Notiomastodon appeared as paraphyletic in one of the most parsimonious trees recovered by this author.

Mothé et al. (2013) proposed a phylogenetic hypothesis for Proboscidea, with the South America taxa represented only by $C$. hyodon and N. platensis. The genus Stegomastodon was represented by one of the North American species. The result was a consensus tree with a large polytomy, but included a monophyletic clade including the South American taxa.

The most recent phylogenetic hypothesis for South American proboscideans comprised a deep review of non-amebelodontine trilophodont gomphotheres, especially focused on the brevirostrine genera: Cuvieronius, Notiomastodon, Rhynchotherium, Stegomastodon and Sinomastodon (Mothé et al., 2016). For the first time in a cladistic analysis of trilophodont gomphotheres, the genera Rhynchotherium and Cuvieronius were recovered as sister-taxa, and all the trilophodont brevirostrine genera were recovered in a monophyletic clade (as previously recovered by Ferretti, 2010). The results force reconsideration of a hypothesis of close relationship between the Asian genus Sinomastodon and the clade including South American taxa together with Rhynchotherium; although Sinomastodon is described as having several convergent characters with New World taxa, especially Stegomastodon and Notiomastodon (Lucas, 2013). The North American species of Stegomastodon was positioned as the sister-group of this clade (Mothé et al., 2016). The trilophodont brevirostrine gomphothere lineage was supported by four unambiguous synapomorphies: two features on the upper tusks (upturned and slightly diverging), the absence of lower incisors and the brevirostrine condition of the mandibular symphysis (Fig. 5).

One of the most important additions in recent studies is the significance of the use of polymorphisms, individual and ontogenetic variations in coding characters in phylogenetic analyses (Mothé et al., 2016). Mothé et al. (2016) phylogenetic analyses considered Cuvieronius hyodon as a tetrabelodont gomphothere (a condition where the proboscidean has a pair of upper and a pair of lower incisors), and did not consider the high variation in upper tusks, wear patterns, and the complexity of molars in Notiomastodon, Cuvieronius and Stegomastodon. In addition, the use of clearly stated taxonomic classifications, a large sample of immature to senile individuals (somewhat rare for fossil samples, proboscideans in the New World being an exception) and well-defined characters are extremely important to improve the resolution of phylogenetic hypotheses on extinct taxa.

\subsection{Paleoecology}

Over the past few years, there have been an increasing number of contributions about the ancient feeding ecology of South American proboscideans. Those studies widely included inferences from analysis of carbon and oxygen isotopes from mineralized tissues (MacFadden, 2000; Prado et al., 2003, 2005; Sánchez et al., 2003, 2004; Gutiérrez et al., 2005; Alberdi et al., 2008; Silva, 2008; Viana et al., 2011; Domingo et al., 2012; Dantas et al., 2013; Lopes et al., 2013), analyses of tooth enamel microwear (Asevedo et al., 2012; Asevedo, 2015), evaluation of plant microfossils recovered from tooth calculus (Asevedo et al., 2012, 2014) and functional morphology of the mandibular apparatus (Borges-Silva et al., 2015).

The paleoecological inferences suggest similar generalist feeding habits for Notiomastodon platensis and Cuvieronius hyodon. Therefore, the paleodiet of these proboscideans, which was constituted by herbaceous and woody plants, was influenced by phyto-physiognomy. A generalist-opportunistic strategy was a very important factor for the wide distribution of South American proboscideans, which likely occupied a wide range of environmental conditions (both cold and warm habitats, humid and arid environments - such as the tropical Andes, the Argentinean GranChaco and Pampas, and the semi-arid Caatinga in Brazil, respectively (Asevedo, 2015; Mothé and Avilla, 2015).

Mothé et al. (2010) inferred that the herd composition of South American proboscideans (specially $N$. platensis) was similar to extant elephants, in which family units include individuals in several age classes with similar feeding strategies. Diet composition of South American proboscideans may have varied on a seasonal or regional basis and, similarly to extant proboscideans, the calves would preferentially select plant portions with higher nutritional content (foliage, herbaceous and fruits), along with breast-feeding (Shoshani and Tassy, 1996; Asevedo, 2015; Asevedo et al., 2015).

Ecological inferences for $C$. hyodon and $N$. platensis during the middle Pleistocene are scarce, and restricted to the Bolivian (Tarija and Ulloma) and Argentinian (Ensenada, La Plata and Arroyo Pavón, in Buenos Aires province) localities, because these are the only records of both species recognized to the middle Pleistocene. Although grasses are recorded as food item in the diet of $C$. hyodon from Tarija, Bolivia (MacFadden, 2000;; Asevedo, 2015), a mixed feeder habit is attributed to this species in this locality (Sánchez et al., 2004; Asevedo, 2015). In contrast, at the same time N. platensis from Buenos Aires Province had a mixed diet with high frequency of $\mathrm{C}_{3}$ plants (Sánchez et al., 2004).

In the late Pleistocene, C. hyodon from Ayusbamba, Peru, inhabited a mixed feeder environment with great amount of $C_{4}$ grasses (Sánchez et al., 2004; Domingo et al., 2012). It is important to highlight that Ayusbamba has an absolute date of $1.3 \pm 0.2$ Mya (Bouchez et al., 1984; see more details in Section 3.5), which represents the transition moment from middle to late Pleistocene. Nevertheless, paleoecological studies using isotopic data refer and discuss this locality as late Pleistocene (Sánchez et al., 2004; Domingo et al., 2012; Asevedo, 2015).

Late Pleistocene records of $N$. platensis are more common and the paleoecological traits during this time period are the most studied and known. Notiomastodon platensis had a diet composed by $\mathrm{C}_{4}$ grasses in the coast of Ecuador (Santa Elena and La Carolina; Prado et al., 2003; Sánchez et al., 2004; Domingo et al., 2012) and fed on $C_{3}$ mixed vegetation in the Andean region of Peru 


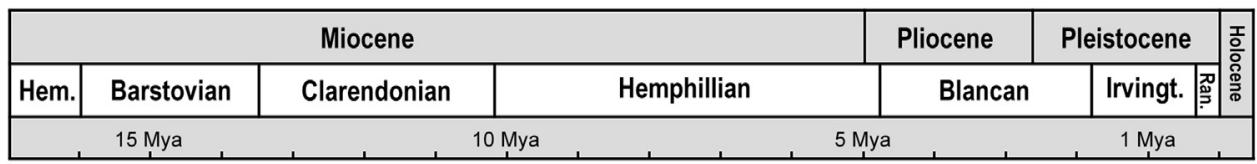

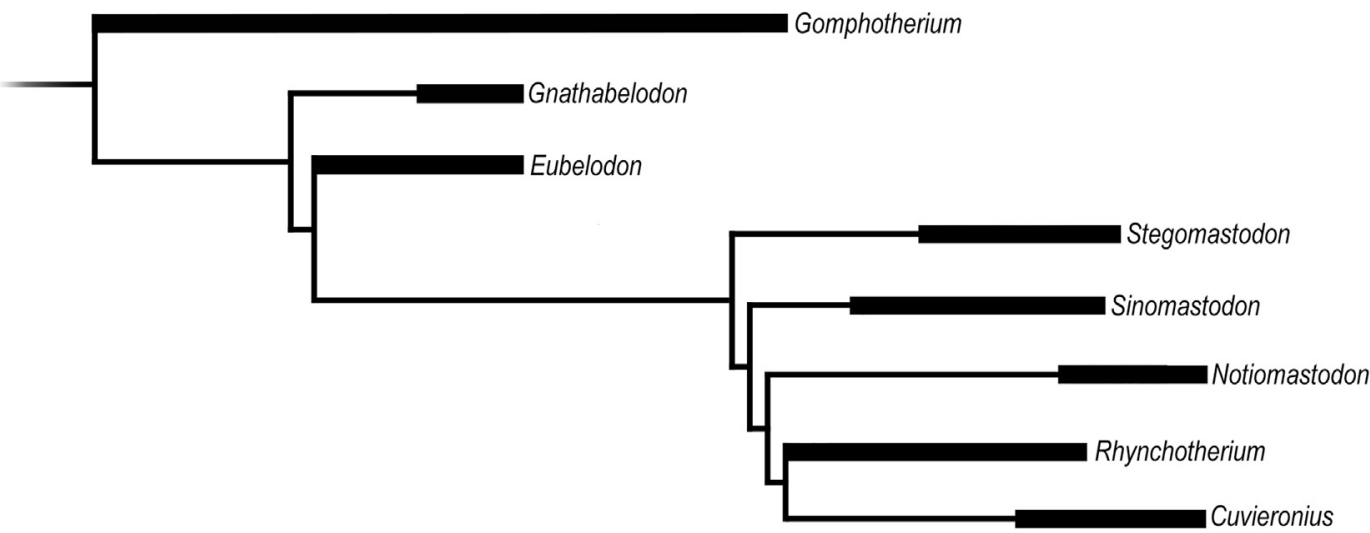

Fig. 5. Phylogenetic position of Cuvieronius hyodon and Notiomastodon platensis among non-amebelodontine trilophodont-gomphotheres (modified from Mothé et al., 2016).

(Leclishpampa; Prado et al., 2003; Sánchez et al., 2004; Domingo et al., 2012). This taxon was a grazer (feeding on $C_{3}$ grasses) in the high plains of Bogotá (an Andean locality), in Colombia (Asevedo, 2015). Notiomastodon platensis from the Brazilian Intertropical Region (sensu Cartelle, 1999), northeastern South America, had a $\mathrm{C}_{4}$ grazer or grass-dominated mixed feeder diet (Silva, 2008; Viana et al., 2011; Dantas et al., 2013; Asevedo, 2015; Asevedo et al., 2015). A transition from semi-arid to more humid biomes (from Caatinga to Atlantic Forest, respectively) was evidenced by the mixed feeding diet attributed to this proboscidean in some localities in the Brazilian Intertropical Region (Coronel João Sá and Toca dos Ossos, Bahia State; Araxá, Minas Gerais State; and São José de Itaboraí, Rio de Janeiro State) (Sánchez et al., 2004; Asevedo et al., 2012; Dantas et al., 2013; Asevedo, 2015). Southern localities of Brazil (Dom Pedrito and Santa Vitória do Palmar, Rio Grande do Sul State) record $N$. platensis as a mixed $C_{3}-C_{4}$ feeder, which probably inhabited open environments with forest fragments (Asevedo, 2015). Notiomastodon platensis from Argentina had great dietary diversity, including those from Gran-Chaco lowlands (Formosa Province) that had a generalist diet composed by $C_{3}$ plants and those from Santiago del Estero Province that had a generalist $C_{3}-C_{4}$ diet, although a $\mathrm{C}_{4}$ diet was inferred for these specimens through stable isotope analysis (Alberdi et al., 2008). Grasses were probably the most frequent food items of $N$. platensis in other Argentinian provinces (Asevedo, 2015), including a grass-dominated mixed feeder diet in Cordoba and Santa Fé Provinces, a $\mathrm{C}_{4}$ grazer diet in San Luis Province and a $C_{3}$ grazer diet in Entre Ríos Province (Domingo et al., 2012; Asevedo, 2015). A more diversified diet was identified for $N$. platensis from Buenos Aires, including generalist, grazer and browser diets, with great use of $C_{3}$ plants (Sánchez et al., 2004; Domingo et al., 2012; Asevedo, 2015). Similarly, $C_{3}$ plants were possibly an important part of the diet for the Chilean N. platensis (localities between 32 and $40^{\circ} \mathrm{S}$ ), which probably had mixed feeding and browse diets (Asevedo, 2015).

A latitudinal gradient of $C_{3}$ and $C_{4}$ plant dominance in South America lowlands was recognized by Asevedo (2015) to N. platensis, which mostly had a diet based on $\mathrm{C}_{4}$ plants in low latitude localities; a mixed $\mathrm{C}_{3}-\mathrm{C}_{4}$ diet in mid-latitudes and a $\mathrm{C}_{3}$ diet in localities close to $33^{\circ} \mathrm{S}$ or more. This same latitudinal gradient was recovered by MacFadden et al. (1999) in a stable isotope study of the fossil horse Equus in the late Pleistocene of South America.
The lack of sympatry between C. hyodon and N. platensis in the countries that they are both recorded (Peru, Ecuador and Bolivia) may suggest competitive exclusion between them during middlelate Pleistocene. The evolutionary history of proboscideans indicates that sympatry of closely related species is very rare, and the most common ecological pattern includes distantly-related species from different lineages in sympatry. One example is the sympatry among gomphotheres, mastodons (Mammutidae) and mammoths (Elephantidae) during the Pleistocene in Central and North Americas (Lucas and Alvarado, 2010). This evolutionary characteristic associated to the more specialized feeding habits of mammoths and mastodons (Rivals et al., 2015; Pérez-Crespo et al., 2016), may acted as a barrier to both lineages at the Panamanian Isthmus, creating an ecological barrier (filter) to their migration to South America (Dudley, 1996; Pérez-Crespo et al., 2016).

\subsection{Origin, chronostratigraphy and extinction}

The oldest undisputed record of Proboscidea in South America is a fragmented vertebra from the upper section of the Uquia Formation (younger than 2.5 Mya; Reguero et al., 2007) from the earliest Pleistocene of Argentina (Sanandresian Stage/Age, Cione et al., 2015). Unfortunately, this fossil does not preserve any diagnostic feature of Notiomastodon nor Cuvieronius. The next younger age, Early to Middle Pleistocene (the Ensenadan; Soibelzon, 2008), is represented by several deposits along the coast of the Buenos Aires Province in Argentina, which preserved a great abundance and diversity of mammalian fossils (Soibelzon, 2008; Soibelzon et al., 2008; Cione et al., 2015). Even though paleontologists have been recovering proboscideans from these deposits since the end of the 19th century (Soibelzon, 2008; Soibelzon et al., 2008), some previous studies did not consider proboscideans part of Ensenadan faunas (Tonni et al., 1992). The exclusion resulted from the fragmentary nature and scarcity of Ensenadan proboscidean records and because of the historical lack of clarity around taxonomy for South American proboscideans (Fig. 2). However, a pair of tusks (MLP-8-63), slightly upcurved and without torsion (Fig. 3A), from San Nicolás de los Arroyos (Buenos Aires, Argentina), and some other remains from the "Toscas del Rio de La Plata" (MACN Pv 10054 and 16277) clearly represent N. platensis (Cabrera, 1929; Mothé et al., 2012; Mothé and Avilla, 2015). Thus, this indicates 
that Notiomastodon platensis was present, at least, by the Early Pleistocene (Ensenadan) in South America (Soibelzon, 2008). Although $N$. platensis is recorded continuously from the Early Pleistocene to earliest Holocene ( $11 \pm 6 \mathrm{ka}$; Dantas et al., 2013), most remains are from the Late Pleistocene, such as those from the Águas de Araxá assemblage (60 $\pm 5 \mathrm{ka}$; Simpson and Paula Couto, 1957; Avilla et al., 2013), Chuí Creek, in Southern Brazil (44 $\pm 3 \mathrm{ka}, 52 \pm 7$ and $80 \pm 10 \mathrm{ka}$, Lopes et al., 2013), Tanque Loma (23.4-18 ka; Lindsey and Lopez, 2015), Quebrada Colorada, Chimborazo, in Ecuador (41.0-40.0 ka; Román-Carrión, unpublished results), Monte Verde (11.8 $\pm 200 \mathrm{ka}$ and $13.5 \pm 250 \mathrm{ka}$; Dillehay, 1989; Labarca Encina and Alberdi, 2011; Recabarren et al., 2014), Nochaco, Región de Los Lagos (16.1 \pm 750 ka, Recabarren et al., 2014) and Mupulmo, Osorno, in Chile $(18,700 \pm 900 \mathrm{ka}$; Recabarren et al., 2014).

There is now general agreement that Stegomastodon was restricted to North America, Notiomastodon platensis is a senior synonym of both Stegomastodon platensis and S. waringi, and Stegomastodon and Notiomastodon are not closely related (Fig. 5; Mothé et al., 2012, 2016; Mothé and Avilla, 2015). Therefore, there is only one possible biogeographic explanation for the presence of $N$. platensis in South America, and it indicates dispersion from the north (Central or North Americas, or both). We hypothesize that $N$. platensis has not been found outside South America due to a lack of studies on Plio-Pleistocene outcrops in Central America. However, there is a Gomphotheriidae last molar from Costa Rica that shows some similarities to N. platensis (A. Valério and C. Laurito, pers. comm.), but more diagnostic materials are needed to confirm its identification. The discovery or confirmation of a Central American $N$. platensis may suggest that this proboscidean migrated through the Panamanian Isthmus into South America sometime before its oldest austral record (Early Pleistocene, Ensenadan; Cabrera, 1929; Soibelzon et al., 2008). The Great American Biotic Interchange (GABI) was one of the most important biogeographic event for the South American mammalian evolution. Woodburne (2010) recognized the principal phases of GABI, as GABI 1 (2.6-2.4 Ma), GABI 2 (around $1.8 \mathrm{Ma}$ ), GABI 3 (around 1.0 to $0.8 \mathrm{Ma}$ ) and GABI 4 $(0.125 \mathrm{Ma})$. Based on the oldest record of Notiomastodon in South America, we hypothesize that the dispersion of this taxon was possibly part of GABI 2 (Fig. 6).

The wide distributional pattern of Notiomastodon during the Late Pleistocene may suggest that this proboscidean reached this extensive geographic range just before its extinction in the Early Holocene. Even though two hypotheses (climatic change and human action) are frequently evoked to explain South American megafauna extinction, the causal mechanism for the extinction of $N$. platensis is still under discussion. There is currently only one study suggesting a climatic cause for the extinction of Notiomastodon platensis, but this is an earlier ( $60 \mathrm{ka})$ extirpation, possibly not related to the extinction of proboscideans in the Pleistocene-Holocene transition (Avilla et al., 2013). However, that event is consistent with a hypothesis that the sum of several regional disappearances along the Late Pleistocene led to the extinction of proboscideans in South America (Ficcarelli et al., 1997). Only a few fossils of $N$. platensis were found in association with human remains and/or artifacts: Taima-Taima, Muaco, Cucuruchu (Venezuela), Tagua-Tagua, Monte Verde (Chile), Tibitó (Colombia) and Lagoa Santa (Brazil) (Politis et al., 1995; Dillehay, 1989; Mothé et al., unpublished results). These associations are suggestive of human usage of proboscideans in their diet, but this association does not suggest that only humans led $N$. platensis to extinction. Most studies suggest a synergy between climate and human impacts as the cause for the extinction of this proboscidean (e.g., Cione et al., 2003; Lima-Ribeiro et al., 2013).

Defining the temporal range of Cuvieronius hyodon in South America is an arduous task. Coltorti et al. (2007) indicated that the Tarija remains are Late Pleistocene in age ( $<44 \mathrm{ka}$; Fig. 6), representing the most recent record for $C$. hyodon in South America. In contrast, MacFadden (2000) and MacFadden et al. (2013) dated fossils and presented a magnetostratigraphy from the same locality that suggested that the Tarija remains may represent the oldest age for Cuvieronius hyodon in South America (Middle Pleistocene, $0.76 \pm 0.03$ Mya; Fig. 6). Another Middle Pleistocene record of Cuvieronius hyodon is a skull from La Huaca, Piura, in Peru, dated to $304 \pm 54$ ka (U-series; Falgueres et al., 1994). Consequently, the $C$. hyodon from La Huaca could be the earliest, if we make allowances for Coltorti et al. (2007) or the latest, if we accept the results of MacFadden et al. (2013). There is an electron spin resonance spectrometry date associated with $C$. hyodon specimens from Ayusbamba, Cuzco, Peru (1.3 \pm 0.2 Mya; Bouchez et al., 1984), but this age inference may be inaccurate due the limitations of electron spin resonance (Schellmann et al., 2008).

Alberdi and Prado (1995) hypothesized that C. hyodon dispersed into South America between Late Pliocene and Early Pleistocene. However, the absolute ages for C. hyodon in South America do not support such interpretation. This taxon probably migrated from Central America after the development of the Panamanian Isthmus as part of the GABI 3 (Early Bonaerian, Middle Pleistocene; ArroyoCabrales et al., 2007), especially when considering absolute dating of $760 \mathrm{ka}$ (MacFadden et al., 2013). However, if we take into account the dating for Tarija by Coltorti et al. (2007), then, the earliest record for C. hyodon in South America would be around $305 \mathrm{ka}$ (Falgueres et al., 1994). This would suggest that this taxon migrated into South America between GABI 3 and 4. The oldest record of $C$. hyodon

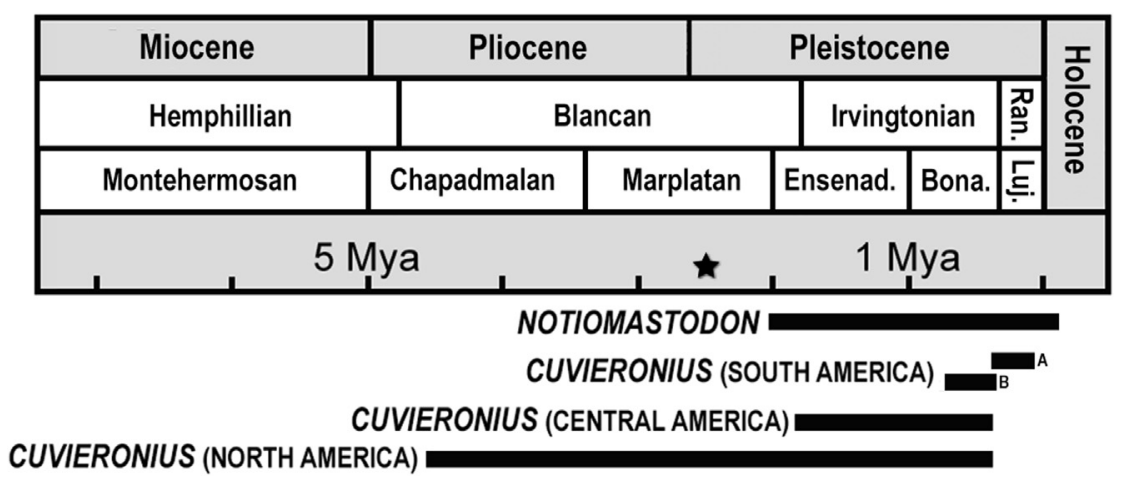

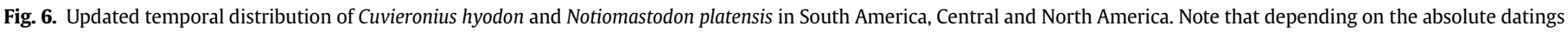
considered, two hypothesis explain the temporal range of Cuvieronius in South America. The black star represents the oldest proboscidean record in South America. 
in Central America is from the Irvingtonian North American Land Mammal Age (NALMA), in El Salvador (correlated to Ensenadan, Early to Middle Pleistocene; Cisneros, 2005; Lucas and Alvarado, 2010). Thus, it likely precedes the oldest South American record independent of the two proposed absolute dates for Tarija specimens.

One of the latest records of Cuvieronius hyodon in North America is from "El Fin del Mundo", an archaeological site in Sonora, Northwestern Mexico. This record is dated to $11,550 \pm 60{ }^{14} \mathrm{C}$ yBP (13,390 Cal years), and represents the first evidence for $C$. hyodon as Clovis culture prey (Sánchez et al., 2014). However, we emphasize that Cuvieronius remains were never found in archaeological sites in South America (Boule and Thevenin, 1920; Lucas, 2008; Mothé and Avilla, 2015), and the records previously associated with Chilean archaeological sites (Tagua-Tagua and Monte Verde, Frassinetti and Alberdi, 2000) were attributed to $N$. platensis (Mothé and Avilla, 2015).

Even when considering the two most recent ages for South American C. hyodon (Tarija around 44 ka, Coltorti et al., 2007; or, Piura about 304 ka, Falgueres et al., 1994), this proboscidean disappeared long before humans reached South America (around 18-14 ka; Dillehay et al., 2015) and prior to the extinction of $N$. platensis and other megafauna (around 11 ka or even more recent).

\section{Conclusions}

After a long, complex and confusing taxonomic history, a stable nomenclature for South American proboscideans is proposed, based on the recognition of two species, Notiomastodon platensis and Cuvieronius hyodon. Both species occurred from the highlands of the Andes to the lowlands of South America, but $C$. hyodon had a more restricted distribution than the widespread $N$. platensis. The South American proboscideans are not closely related; they represent independent lineages. A clade including $C$. hyodon and Rhynchotherium is the sister-taxon of Notiomastodon platensis.

A generalist-opportunist alimentary strategy is recognized for both South American proboscideans. A similar alimentary strategy and the absence of sympatry between them may support a hypothesis of competitive exclusion. A latitudinal gradient of $C_{3}$ and $\mathrm{C}_{4}$ plants is recorded for in the lowlands of the South America based on Late Pleistocene $N$. platensis diet. Notiomastodon platensis from low latitude localities have a more frequent $\mathrm{C}_{4}$ diet and, in localities with high latitudes, the dominant pattern is for $C_{3}$ grazing. In between these two extremities, a gradient from $C_{3}$ to $C_{4}$ plants dominance diets is inferred.

The earliest proboscidean record in South America is from the earliest Pleistocene of "Uquian" outcrops in Argentina. Unfortunately, this record cannot be attributed with confidence to either of the two South American species. The oldest known record of $N$. platensis is from the Ensenadan of Argentina, suggesting that it migrated into South America during GABI 2. Notiomastodon platensis had a continuous record from the Early Pleistocene to Early Holocene, when it became extinct. The cause for this extinction is likely the same hypothesized for the loss of other megafauna, and it is probably a synergy of human impacts and climatic changes during the Pleistocene/Holocene transition. Conversely, Cuvieronius hyodon probably reached South America long after Notiomastodon platensis, in the GABI 3 or in between GABI 3/GABI 4. Its extinction occurred much earlier than $N$. platensis, and it was likely unrelated to the events that led to extinctions during the Pleistocene/Holocene transition.

\section{Acknowledgements}

We want to dedicate this paper to Admiral Ibsen de Gusmão Câmara (In memoriam), Dr. Larry Agenbroad (In memoriam), Dr.
Castor Cartelle, Dr. Bruce MacFadden, Dr. Pascal Tassy, Dr Mario Cozzuol, Dr. Marco Ferretti, Dr. Alexander Kellner, Dr. Ana Valério, MSc. César Laurito, Dr. Spencer Lucas and Dr. Gary Morgan, who discussed and encouraged the authors D. Mothé and L. Avilla to pursue a stability and clear definition for the taxonomy and systematics of South American proboscideans. The authors are grateful to Dr. Jim Mead, for the invitation to contribute to this special volume, and to all curators of the paleontological collections where South American proboscideans specimens are housed, for allowing the access that supported this study and to Dr. Daniel Perea, Dr. Martin Ubilla, Dr. Rodolfo Salas, MSc. Ednair Rodrigues Nascimento for suggestions and discussions. We would like to thank the referees, Dr. Spencer Lucas and Dr. Marco Ferretti, and the guest editor, Dr. Christopher Jass, for the suggestions, comments and general improvements on the manuscript. This work was funded by Conselho Nacional de Desenvolvimento Científico e Tecnológico (140453/2012-01, 201081/2014-8 - DM; 248772/2013-9 - LSA), Coordenação de Aperfeiçoamento de Pessoal de Nível Superior (CAPES/PNPD/2016 - DM) and Fundação Carlos Chagas de Amparo à Pesquisa do Estado do Rio de Janeiro (E-26/100.246/2014 - DM; 204036- E_25/2014-Jovem Cientista do Nosso Estado - LSA).

\section{Appendix A. Supplementary data}

Supplementary data related to this article can be found at http:// dx.doi.org/10.1016/j.quaint.2016.08.028.

\section{References}

Alberdi, M.T., Prado, J.L., 1995. Los mastodontes de América del Sur. In: Alberdi, M.T. Leone, G., Tonni, E.P. (Eds.), Evolución biológica y climática de la Región Pampeana durante los últimos 5 millones de años. Un ensayo de correlación con el Mediterráneo occidental. Monografías del Museo Nacional de Ciencias Naturales, CSIC, España, pp. 277-292.

Alberdi, M.T. Prado, J.L., 2016. Fossil Gomphotheriidae from Argentina. In: Agnolin, F.L., Lio, G.L., Brisson Egli, F., Chimento, N.R., Novas, F.E. (Eds.), Historia Evolutiva y Paleobiogeográfica de los Vertebrados de América del Sur. Contribuciones del MACN 6, Museo Argentino de Ciencias Naturales "Bernardino Rivadavia", Buenos Aires, Argentina, pp. 275-283.

Alberdi, M.T., Cartelle, C., Prado, J.L., 2002. El registro de Stegomastodon (Mammalia, Gomphotheriidae) en el Pleistoceno superior de Brasil. Revista Española de Paleontología 17 (2), 217-235.

Alberdi, M.T., Prado, J.L., Salas, R., 2004. The Pleistocene Gomphotheriidae (Proboscidea) from Peru. Neues Jahrbuch für Geologie und Paläontologie Abhandlungen 231 (3), 423-452.

Alberdi, M.T., Prado, J.L., Ortiz-Jaureguizar, E., Posadas, P., Donato, M., 2007. Historical Biogeography of Trilophodont Gomphotheres (Mammalia, Proboscidea) Reconstructed Applying Dispersion Vicariance Analysis, vol. 8. Cuadernos del Museo Geominero, Instituto Geologico Minero de España, pp. 9-14.

Alberdi, M.T., Cerdeño, E., Prado, J.L., 2008. Stegomastodon platensis (Proboscidea, Gomphotheriidae) en el Pleistoceno de Santiago del Estero, Argentina. Ameghiniana 45 (2), 257-271.

Ameghino, F., 1888. Rápidas diagnosis de algunos mamíferos fósiles nuevos de la República Argentina. Imprenta de Pablo E. Coni e Hijos, Buenos Aires, pp. 1-17.

Ameghino, F., 1889. Contribucion al conocimiento de los mamiferos fosiles de la República Argentina: Obra escrita bajo los auspicios de la Academia nacional de ciencias de la República Argentina para ser presentada a la Exposicion universal de Paris de 1889, vol. 6. PE Coni e hijos, Buenos Aires.

Ameghino, F., 1891. Mamíferos y aves fósiles argentinos. Especies nuevas, adiciones y correcciones. Revista Argentina de Historia Natural 1, 240-259.

Ameghino, F., 1902. Cuadro sinóptico de las formaciones sedimentarias, terciarias y cretáceas de la Argentina en relación con el desarrollo y descendencia de los mamíferos. Anales del Museo Nacional de Buenos Aires 8 (3), 1-12.

Arroyo-Cabrales, J., Polaco, O.J., Laurito, C., Johnson, E., Alberdi, M.T., Zamora, V.A.L., 2007. The proboscideans (Mammalia) from Mesoamerica. Quaternary International 169, 17-23.

Asevedo, L., 2015. Paleoecologia alimentar dos gonfotérios (Proboscidea: Mammalia) Pleistocênicos da América do Sul. Pós-graduação em Ciências Biológicas (Biodiversidade Neotropical). Pós-graduação em Biodiversidade Neotropical Universidade Federal do Estado do Rio de Janeiro, Brazil. Master Thesis.

Asevedo, L., Winck, G.R., Mothé, D., Avilla, L.S., 2012. Ancient diet of the Pleistocene gomphothere Notiomastodon platensis (Mammalia, Proboscidea Gomphotheriidae) from lowland mid-latitudes of South America: 
stereomicrowear and tooth calculus analyses combined. Quaternary International 255, 42-52.

Asevedo, L.S., Misumi, S.Y., Barros, M.A., Barth, O.M., Avilla, L.S., Dantas, M.A.T., 2014 Extração polínica dos cálculos dentários de Notiomastodon platensis (Ameghino, 1888) (Gomphotheriidae: Mammalia) do Pleistoceno Tardio de Santa Vitória do Palmar, pp. 2-3. Rio Grande do Sul, Brasil. Paleo RJ/ES 2014, Rio de Janeiro, Brazil.

Asevedo, L., Misumi, S.Y., Barros, M.A., Barth, O.M., Avilla, L.S., Dantas, M.A.T., 2015 Paleoecologia alimentar dos gonfoteríideos (Proboscidea: Mammalia) Pleistocênicos da América do Sul. In: XXIV Congresso Brasileiro de Paleontologia, Crato, Brazil, pp. 1-2

Avilla, L.S., Figueiredo, A.M.G., Kinoshita, A., Bertoni-Machado, C., Mothé, D., Asevedo, L., Baffa, O., Dominato, V.H., 2013. Extinction of a gomphothere population from southeastern Brazil: taphonomic, paleoecological and chronological remarks. Quaternary International 305, 85-90.

Borges-Silva, L., Mothé, D., Avilla, L.S., 2015. A morfometria mandibular e sua evolução no hábito pastador dos gonfotéridos trilofodontes brevirostrinos (Proboscidea: Gomphotheriidae) das Américas. In: XXIV Congresso Brasileiro de Paleontologia, Crato, Brazil, pp. 180-181.

Bouchez, R., Lopez-Carranza, E., Ma, J.L., Amosse, J., Piboule, M., Cornu, A., Diebolt, J., Galland, D., Rey, P., De Lumley, H., Ramirez Pareja, J.A., Guérin, C., 1984. Datation par spectrométrie RPE d'émail dentaire fossile dans le domaine de 50000 ans à plusieurs millions d'années. Revue d'Archéométrie 8, 70-79.

Boule, M., Thevenin, A., 1920. Mammiféres fossiles de Tarija. Soudier, Paris pp. $1-256$.

Cabrera, A., 1929. Una revisión de los Mastodontes Argentinos. Revista del Museo de la Plata 32, 61-144.

Campbell Jr., K.E., Frailey, C.D., Romero-Pittman, L., 2000. The late Miocene gomphothere Amahuacatherium peruvium (Proboscidea: Gomphotheriidae) from Amazonian Peru: implications for the great American faunal interchange. Boletín de Estudios Regionales IGEMMET 23, 1-152.

Campbell, K.E., Frailey, C.D., Romero-Pittman, L., 2009. In defense of Amahuacatherium (Proboscidea: Gomphotheriidae). Neues Jahrbuch für Geologie und Paläontologie A 252 (1), 113-128.

Cartelle, C., 1999. Pleistocene mammals of the cerrado and Caatinga of Brazil. In: Eisenberg, J.F., Redford, K.H. (Eds.), Mammals of the Neotropics, vol. 3. The University of Chicago Press, Chicago, IL, pp. 27-46.

Cione, A., Tonni, E.P., Soibelzon, L.H., 2003. The broken zig-zag: Late Cenozoic large mammal and turtle extinction in South America. Revista del Museo Argentino de Ciencias Naturales 5 (1), 1-19.

Cione, A.L. Gasparini, G.M., Soibelzon, E., Soibelzon, L.H., Tonni, E.P., 2015. The Great American Biotic Interchange in Southern South America: Land Mamma Biostratigraphy, Climatic Evolution and Faunal Integration. Springer Briefs in Earth System Sciences. Springer, New York-London.

Cisneros, J.C., 2005. New Pleistocene vertebrate fauna from El Salvador. Revista Brasileira de Paleontologia 8 (3), 239-255.

Coltorti, M., Abbazzi, L., Ferretti, M.P., Iacumin, P., Ríos, F.P., Pellegrini, M., Pieruccini, M., Tito, G., Rook, L. 2007. Last glacial mammals in South America: a new scenario from the Tarija Basin (Bolivia). Naturwissenschaften 94 (4), 288-299.

Cozzuol, M.A., Mothé, D., Avilla, L.S., 2012. A critical appraisal of the phylogenetic proposals for the South American Gomphotheriidae (Proboscidea: Mammalia). Quaternary International 255, 36-41.

Cuvier, G., 1806. Sur différentes dents du genre des mastodontes, mais d'espèces moindres que celle de l'Ohio, trouvées en plusieurs lieux des deux continents. Annales du Museum d'Histoire naturelle 7, 401-420.

Cuvier, G., 1824. tome. Recherches sur les ossemens fossiles, ou l'on retablit les caracteres de plusieurs animaux dont les revolutions du globe ont detruit les especes, $2^{\text {eme }}$ edition, vol. V. $2^{\text {eme }}$ partie. G. Dufour et E. d'Ocagne, Paris.

Dantas, M.A.T., Dutra, R.P., Cherkinsky, A., Fortier, D.C., Kamino, L.H.Y., Cozzuol, M.A. Ribeiro, A.S., Silva, F.V., 2013. Paleoecology and radiocarbon dating of the Pleistocene megafauna of the Brazilian intertropical region. Quaternary Research 79, 61-65.

Dillehay, T.D., 1989. Monte Verde: a Late Pleistocene Settlement in Chile. In: The Paleo-environment and Site Context, vol. I. Smithsonian Institution Press, Washington, D.C.

Dillehay, T.D., Ocampo, C., Saavedra, J., Sawakuchi, A.O., Vega, R.M., Pino, M. Collins, M.B., Cummings, L.S., Arregui, I., Villagran, X.S., Hartmann, G.A. Mella, M., Gonzalez, A., Dix, G., 2015. New archaeological evidence for an early human presence at Monte Verde, Chile. PLoS One 10 (11), e0141923. http:/ dx.doi.org/10.1371/journal.pone.0141923.

Domingo, L., Prado, J.L., Alberdi, M.T., 2012. The effect of paleoecology and paleobiogeography on stable isotopes of Quaternary mammals from South America. Quaternary Sciences Review 55, 103-113.

Dudley, J.P., 1996. Mammoths, gomphotheres, and the great American fauna interchange. In: Shoshani, J., Tassy, P. (Eds.), The Proboscidea: Evolution and Palaeoecology of Elephants and Their Relatives. Oxford University Press, Oxford pp. 289-295.

Falgueres, C., Fontugne, M., Chauchat, C., Guadelli, J.L., 1994. Radiometric dating o the extinction of the large Pleistocene fauna in Peru. Comptes rendus de l'Academie des sciences. Serie 2319 (2), 261-266.

Ferretti, M.P., 2008. A review of South American proboscideans. Neogene Mammals New Mexico Museum of Natural History and Science Bulletin 44, 381-392.

Ferretti, M.P., 2010. Anatomy of Haplomastodon chimborazi (Mammalia, Proboscidea) from the late Pleistocene of Ecuador and its bearing on the phylogeny an systematics of south American gomphotheres. Geodiversitas 32 (4), 663-721.
Ficcarelli, G., Borselli, V., Herrera, G., Espinosa, M.M., Torre, D., 1995. Taxonomic remarks on the South American mastodons referred to Haplomastodon and Cuvieronius. Geobios 28 (6), 745-756.

Ficcarelli, C., Azzaroli, A., Bertini, A., Coltorti, M., Mazza, P., Mezzabot, C., MorenoEspinosa, M., Rook, L., Torre, D., 1997. Hypothesis on the cause of extinction of the South American mastodons. Journal of South American Earth Sciences 10 (1), 29-38.

Frassinetti, D., Alberdi, M.T., 2000. Revisión y estudio de los restos fósiles de mastodontes de Chile (Gomphotheriidae): Cuvieronius hyodon, Pleistoceno superior. Estudios Geologicos 56, 197-208.

Fischer, G., 1814. Zoognosia-tabulis Synopticis Illustrta, vol. 3. Typis Nicolai Sergeides Vsevolozsky, Moscow, pp. 1-694.

Gutiérrez, M., Alberdi, M.T., Prado, J.L., Perea, D., 2005. Late Pleistocene Stegomastodon (Mammalia, Proboscidea) from Uruguay. Neues Jahrbuch fur Geologie und Palaontologie-Monatshefte 11, 641-662.

Hoffstetter, R., 1950. Observaciones sobre los mastodontes de Sud América y especialmente del Ecuador. Haplomastodon, subgn. nov. de Stegomastodon, vol. 1. Publicaciones de la Escuela Politécnica Nacional, pp. 1-51.

Hoffstetter, R., 1952. Les mammiferes Pleistocenes de la République de l'Equateur. Mémoires Société Géologique de France 66, 1-391.

Holland, W.J., 1920. Fossil mammals collected at Pedra Vermelha, Bahia, Brazil, by Gerald a waring. Annals of Carnegie Museum 13, 224-232.

Hooghiemstra, H., Ran, T.H., 1994. Late Pliocene-Pleistocene high resolution pollen sequence of Colombia: an overview of climatic change. Quaternary International 21, 63-80.

Internacional Commission on Zoological Nomenclature, 1999. International Code of Zoological Nomenclature, Fourth Edition. The Natural History Museum, Cromwell Road, London, pp. 1-306.

Labarca Encina, R., Alberdi, M.T., 2011. An updated taxonomic view on the family Gomphotheriidae (Proboscidea) in the final Pleistocene of south-central Chile. Neues Jahrbuch für Geologie und Paläontologie - Abhandlungen 262, 43-57.

Lesson, R.P., 1842. Nouveau Tableau Du Regne Animal: Mammiferes. Arthus-Bertrand, Paris.

Liendo-Lazarte, M., 1946. Algunas consideraciones sobre los Mastodontes de Tarija. Museo Nacional Tiahuanacu, Seccion Paleontología, pp. 1-14.

Lima-Ribeiro, M.S., Faleiro, F.V., Silva, D.P., 2013. Current and historical climate signatures to deconstructed tree species richness pattern in South America. Acta Scientiarum, Biological Sciences 35, 219-231.

Lindsey, E.L., Lopez, E.X.R., 2015. Tanque Loma, a new late-Pleistocene megafaunal tar seep locality from southwest Ecuador. Journal of South American Earth Sciences 57, 61-82.

Lopes, R.P., Ribeiro, A.M., Dillenburg, S.R., Schultz, C.L., 2013. Late middle to late Pleistocene paleoecology and paleoenvironments in the coastal plain of Rio Grande do Sul State, Southern Brazil, from stable isotopes in fossils of Toxodon and Stegomastodon. Palaeogeography, Palaeoclimatology, Palaeoecology 369, 385-394.

Lucas, S.G., 2008. Taxonomic nomenclature of Cuvieronius and Haplomastodon, proboscideans from the plio-pleistocene of the new World. New Mexico Museum Natural History and Science Bulletin 44, 409-415.

Lucas, S.G., 2009a. Case 3480 Mastodon waringi (currently Haplomastodon waringi; Mammalia, Proboscidea): proposed conservation of usage by designation of a neotype. Bulletin of Zoological Nomenclature 66, 164-167.

Lucas, S.G., 2009b. Case 3479 Cuvieronius (Mammalia, Proboscidea): proposed conservation. Bulletin of Zoological Nomenclature 66, 1-6.

Lucas, S.G., 2013. The palaeobiogeography of South American gomphotheres. Journal of Paleogeography 2 (1), 19-40.

Lucas, S.G., Alvarado, G.E., 2010. Fossil Proboscidea from the upper cenozoic of Central America: taxonomy, evolutionary and paleobiogeographic significance, Revista Geológica de América Central 42, 9-42.

Lucas, S.G., Aguilar, R.H., Spielmann, J.A., 2011. Stegomastodon (Mammalia, Proboscidea) from the Pliocene of Jalisco, Mexico and the species-level taxonomy of Stegomastodon. In: Sullivan, E.D. (Ed.), Fossil Record 3, New Mexico Natural History and Science Museum Bulletin 53, pp. 517-553.

Lund, P.W., 1839. Coup d'oeil sur les espéces éteintes de mammifères du Bresil, extrait de quelques mémoires presentés à l'Académie Royal des Sciences de Copenhaghe. Annales des Sciences Naturelles (Zoologie) 2 (11), 214-234.

MacFadden, B.J., 2000. Middle Pleistocene climate change recorded in fossil mammal teeth from Tarija, Bolivia, and upper limit of the Ensenadan LandMammal Age. Quaternary Research 54, 121-131.

MacFadden, B.J., Cerling, T.E., Harris, J.M., Prado, J.L., 1999. Ancient latitudinal gradients of $\mathrm{C} 3 / \mathrm{C} 4$ grasses interpreted from stable isotopes of New World Pleistocene horse (Equus) teeth. Global Ecology and Biogeography 8, 137-149.

MacFadden, B.J., Zeitler, P.K., Anaya, F., Cottle, J.M., 2013. Middle Pleistocene age of the fossiliferous sedimentary sequence from Tarija, Bolivia. Quaternary Research 79, 268-273.

Madden, C.T., 1984. The Proboscidea of south America. In: 1984 Annual Meeting of the Geological Society of America, Reno, Nevada Abstracts with Program 12, 474.

Mothé, D., Avilla, L.S., 2015. Mythbusting evolutionary issues on South American Gomphotheriidae (Mammalia: Proboscidea). Quaternary Science Reviews 110, 23-35.

Mothé, D., Avilla, L.S., Winck, G.R., 2010. Population structure of the gomphothere Stegomastodon waringi (Mammalia: Proboscidea: Gomphotheriidae) from the Pleistocene of Brazil. Anais da Academia Brasileira de Ciências 82, 983-996.

Mothé, D. Avilla, L.S., Cozzuol, M.A., Winck, G.R., 2012. Taxonomic revision of the quaternary gomphotheres (Mammalia: Proboscidea: Gomphotheriidae) from the South America lowlands. Quaternary International 276-277, 2-7. 
Mothé, D., Avilla, L.S., Cozzuol, M., 2013. The South American gomphotheres (Mammalia, Proboscidea, Gomphotheriidae): taxonomy, phylogeny and biogeography. Journal of Mammalian Evolution 20, 23-32.

Mothé, D., Ferretti, M.P., Avilla, L.S., 2016. The dance of tusks: rediscovery of lower incisors in the Pan-American proboscidean Cuvieronius hyodon revises incisor evolution in Elephantimorpha. PLoS One 11 (1), e0147009. http://dx.doi.org/ 10.1371 /journal.pone.0147009.

Osborn, H.F., 1923. New subfamily, generic, and specific stages in the evolution of the Proboscidea. American Museum Novitates 99, 1-4.

Osborn, H.F., 1924. Additional generic and specific stages in the evolution of the Proboscidea. American Museum Novitates 154, 1-5.

Osborn, H.F., 1926. Additional new genera and species of the mastodontoid Proboscidea. American Museum Novitates 238, 1-16.

Osborn, H.F., 1936. Proboscidea. A Monograph of the Discovery, Evolution, Migration and Extinction of the Mastodons and Elephants, Vol. 1-Moeritherioidea, Deinotheiroidea, Mastodontoidea. The American Museum Press, New York, pp. 1-802.

Perea, D., Alberdi, M.T., 2015. Los gonfotéridos (Mammalia, Proboscidea) de Uruguay: taxonomía, estratigrafía y cronología. Estudios Geológicos 71 (2), e036. http://dx.doi.org/10.3989/egeol.41864.346.

Pérez-Crespo, V.A., Prado, J.L., Alberdi, M.T., Arroyo-Cabrales, J., Johnson, E., 2016. Diet and habitat for six American Pleistocene roboscidean species using carbon and oxygenstable isotopes. Ameghiniana 53 (1), 39-51.

Politis, G., Prado, J.L., Beukens, R.P., 1995. The human impact in PleistoceneHolocene extinctions in South America. In: Johson, E. (Ed.), Ancient Peoples and Apes. Museum of Texas Tech University Press, Lubbock, pp. 187-205.

Prado, J.L., Alberdi, M.T., 2008. A cladistic analysis among trilophodont gomphotheres (Mammalia, Proboscidea) with special attention to the South American genera. Palaeontology 51, 903-915.

Prado, J.L., Alberdi, M.T., Azanza, B., Sánchez, B., 2001. Quantitative relationship between climate and changes in mammal diversity during the late Pleistocene-Holocene in the Pampean Region (Argentina). Acta Palaeontologica Polonica 46, 261-276.

Prado, J.L., Alberdi, M.T. Gómez, G.N., 2002. Late Pleistocene gomphothere (Proboscidea) remains from the Arroyo Tapalqué locality (Buenos Aires, Argentina) and their taxonomic and biogeographic implications. Neues Jahrbuch für Geologie und Paläontologie - Abhandlungen 225, 275-296.

Prado, J.L., Alberdi, M.T., Sánchez, B., Azanza, B., 2003. Diversity of the Pleistocene gomphotheres (Gomphotheriidae, Proboscidea) from South America. Deinsea 9, 347-363.

Prado, J.L., Alberdi, M.T., Azanza, B., Sánchez, B., Frassinetti, D., 2005. The Pleistocene gomphotheres (Proboscidea) from South America. Quaternary International $126,21-30$.

Proaño, J.F., 1922. La Virgen del Dios Chimborazo, Tradiciones Puruhaes. Imprenta "El Observador", Riobamba, pp. 1-23.

Recabarren, O.P., Pino, M., Alberdi, M.T., 2014. La Familia Gomphotheriidae en América del Sur: evidencia de molares al norte de la Patagonia chilena. Estudios Geológicos 70 (1), e001. http://dx.doi.org/10.3989/egeol.41346.273.

Reguero, M.A., Candela, A.M., Alonso, R.N., 2007. Biochronology and biostratigraphy of the Uquía formation (Pliocene-early Pleistocene, nw Argentina) and its significance in the great American biotic interchange. Journal of South American Earth Sciences 23, 1-16.

Rivals, F., Mol, D., Lacombat, F., Lister, A.M., Semprebon, G.M., 2015. Resource partitioning and niche separation between mammoths (Mammuthus rumanus and Mammuthus meridionalis) and gomphotheres (Anancus arvernensis) in the Early Pleistocene of Europe. Quaternary International 379, 164-170.

Sánchez, B., Prado, J.L., Alberdi, M.T., 2003. Paleodiet, ecology, and extinction of Pleistocene gomphotheres (Proboscidea) from pampean region (Argentina). Coloquios de Paleontología 1, 617-625.
Sánchez, B., Prado, J.L., Alberdi, M.T., 2004. Feeding ecology, dispersal, and extinction of south American Pleistocene gomphotheres (Gomphotheriidae, Proboscidea). Paleobiology 30, 146-161.

Sánchez, G., Holliday, V.T., Gaines, E.P., Arroyo-Cabrales, J., Martínez-Tagüeña, N., Kowler, A., Lange, T., Hodgins, G.W.L., Mentzer, S.M., Sanchez-Morales, I., 2014 Human (Clovis)-Gomphothere (Cuvieronius sp.) Association 13,390 Calibrated yBP in Sonora, Mexico. Proceedings of the National Academy of Sciences 111 (3), 10972-10977.

Schellmann, G., Beerten, K., Radtke, U., 2008. Electron spin resonance (ESR) dating of Quaternary materials. Quaternary Science Journal 57, 150-178.

Shoshani, J., 1996. Para-or monophyly of the gomphotheres and their position within Proboscidea. In: Shoshani, J., Tassy, P. (Eds.), The Proboscidea: Evolution and Palaeoecology of Elephants and Their Relatives. Oxford University Press, New York, pp. 149-177.

Shoshani, J., Tassy, P., 1996. The Proboscidea: Evolution and Palaeoecology of Elephants and Their Relatives. Oxford University Press, New York, pp. 1-472.

Shoshani, J., Tassy, P., 2005. Advances in proboscidean taxonomy and classification, anatomy and physiology, and ecology and behavior. Quaternary International $126,5-20$.

Silva, J.L.L., 2008. Reconstituicão paleoambiental baseada no estudo de mamíferos pleistocênicos de Maravilha e Poço das Trincheiras, Alagoas, nordeste do Brasil. Pós-graduação em Geociências, Universidade Federal de Pernambuco, Brazil Ph.D. Thesis.

Simpson, G.G., Paula Couto, C., 1957. The mastodonts of Brazil. Bulletin of American Museum of Natural History 112 (2), 1-65.

Soibelzon, E., 2008. Los Mamíferos del Ensenadense (Pleistoceno Inferior-Medio) del Este de la Región Pampeana, con énfasis en los Xenarthra. Bioestratigrafía, Diversidad y Correlaciones Biogeográficas. Universidad Nacional de La Plata, Argentina. Ph.D. Thesis.

Soibelzon, E., Gasparini, G.M., Zurita, A.E., Soibelzon, L.H., 2008. Análisis faunístico de vertebrados de las "toscas del Río de La Plata" (Buenos Aires, Argentina): um yacimiento paleontológico em desaparición. Revista del Museo Argentino de Ciencias Naturales 10 (2), 291-308.

Tassy, P., 1985. La place des mastodontes miocènes de l'Ancien Monde dans la phylogénie des Proboscidea (Mammalia): hypothèses et conjectures. UPMC, Paris, France. Ph.D. Thesis.

Tassy, P., 1996. Who is who among the Proboscidea. In: Shoshani, J., Tassy, P. (Eds.), The Proboscidea. Evolution and Palaeoecology of Elephants and Their Relatives. Oxford University Press, Oxford, pp. 39-48.

Tobien, H., 1973. On the evolution of mastodonts (Proboscidea, Mammalia). Part 1 the bunodont trilophodont groups. Hessisches Landesamt für Bodenforschung Wiesbaden 101, 202-276.

Tonni, E.P., Alberdi, M.T., Pardo, L., Bargo, M.S., Cione, A.L., 1992. Changes of mammalian assemblages in the pampean region (Argentina) and their relation with the Plio-Pleistocene boundary. Palaeogeography, Palaeoclimatology, Palaeoecology 95, 179-194.

Van der Hammen, 1974. The Pleistocene changes of vegetation and climate in tropical South America. Journal of Biogeography 1, 3-26.

Viana, M.S.S., Silva, J.L.L., Oliveira, P.V., Julião, M.S.S., 2011. Hábitos alimentares em herbívoros da megafauna pleistocênica no nordeste do Brasil. Estudos Geológicos 21 (2), 89-95.

Winge, H., 1906. Jordgundne og nulevende Hovdyr (Ungulata) fra Lagoa Santa, Minas Gerais, Brasilien. Med udsigt over gumlernes indbyrdes slaegtskab, E. Museo Lundii 3 (1), 1-9.

Woodburne, M.O., 2010. The Great American Biotic Interchange: dispersals, tectonics, climate, sea level and holding pens. Journal of Mammalian Evolution 17, 245-264. 